\title{
The Socio-economic and Bio-cultural Significances of Biodiversity Hotspots and Important Habitats in Assosa and Bambasi Woredas of Benshangul Gumuz Regional State, Ethiopia
}

\author{
Dereje Mosissa $^{1 *} \quad$ Getnet Terekegn $^{2} \quad$ Dereje Abebe $^{2} \quad$ Bukayaw Moges $^{2} \quad$ Baye Weday $^{3}$ \\ Yohannes Tamene ${ }^{5}$ \\ 1.Ethiopian Biodiversity Institute Assosa Biodiversity Center, Forest and Rangeland Biodiversity Case team \\ 2.Bureau of Environment Land Administration and Investment \\ 3.Bureau of Culture and Tourism Development \\ 4.Bureau of Agriculture and Rural Development
}

\begin{abstract}
This study was done with the aim of analyzing the socioeconomic and bio-cultural significance of biodiversity of biodiversity hotspot areas in Assosa Zone of Benishangul Gumuz Regional state of Ethiopia. Forests in Ethiopia are threatened by unsustainable uses and conversion to alternative land uses. In spite of the consequences of forest degradation and biodiversity loss and reliance of communities on forests livelihoods, there is little empirical data on the role of biodiversity in livelihoods of the local communities. This study was done in Benishangul Gumuz Regional state, in selected kebeles of Assosa and Bambasi Districts aiming to determin the Socioeconomic and biocultural uses of biodiversity to the local communities living around biodiversity hotspot areas selected. These data were obtained by interviewing 151 households. Forest product market survey was undertaken to determine prices of various forest products for valuation of forest use. Forest income was significant to households contributing $33 \%$ of total household income. Fuel wood contributed $50 \%$, food (27\%), construction material (48\%), and fodder, and thatching material 51\% to household forest income. Absolute forest income and relative forest income (\%) were significantly different across study locations and between ethnic groups. Moreover, floral and faunal diversity was determined through transect walk along straight line in all biodiversity hotspot areas selected (Anbessa, Kolkis and Mender-42 forests). More than 118 plant species and four community types namely: Combretum molle-Croton macrostachyus (community I); Dichrostachys cinerea-Carrisa spinarum (community II); Cordia africana-Terminalia laxiflora community (Community III) and Ziziphus abyssinica- Syzygium guineense community (Community IV) were identified. Moreover, the areas are home to 20 species of mammals, over 60 species of birds, 12 species of fish, and small mammals, bats, reptiles, and amphibians. These results provide valuable information on the role of forest resources to livelihoods and could be applied in developing biodiversity conservation policies for enhanced ecosystem services and livelihoods of the study areas.

Keywords: biodiversity hotspots, bicultural, biodiversity conservation, socioeconomic, floral and faunal diversity, DOI: $10.7176 / \mathrm{JRDM} / 68-03$
\end{abstract}

Publication date:August $31^{\text {st }} 2020$

\section{Introduction}

Background of the study

Historically, biodiversity conservation was generally stated as environmental conservation which has been dominated by attempts to fence off or reserve areas for nature and exclude people from the reserved areas (Adams W, Hulme D, 2001). According to Guthiga PM (2006) this protectionist approach has been labelled as the 'fortress conservation', 'coercive conservation' or 'fence-fine' and it has dominated mainstream thinking in conservation for a long time. Economic incentives refer to specific inducements designed and implemented to influence government bodies, business, non-governmental organizations, or local people to sustainably and responsibly conserve, utilize and manage environmental resources whereas socio-economic incentives mostly reflect livelihood measures that strengthen and diversify the livelihoods of biodiversity users or residents of biodiversity areas (Emerton L, 2000). They aim at influencing people's behavior by making it more desirable for them to conserve, rather than degrading or depleting biodiversity quality through communities' course of their livelihoods' activities (McNeely JA, 1980; UNEP, 2004)

According to IUCN (2000) many of the most biodiversity rich ecosystems and species in Eastern Africa lie in remote rural areas that are physically or financially beyond the reach of government environmental and protected areas agencies. Their conservation depends primarily on the actions of local communities. Meanwhile, many of these communities are poor, must cope with a limited and insecure livelihood base, and often have few alternatives but to depend on biodiversity for their day-to-day subsistence and income. The provision of socio-economic incentives for these community members to conserve biodiversity is of paramount importance since community economic incentives are based on allowing local communities opportunity to benefit from conservation (McNeely JA, 1980; Panayotou T, 1994). 
Ethiopia has been acknowledged as one of the most important nations in Africa for its biodiversity (EBI, 2015). The initiatives of allocating protected areas in the country go in line with rehabilitation initiatives which partly enhance the existing biodiversity conservation including Mountains, Wetlands, Marine and Fresh Water Areas, forest reserves and partly enclose, improve and establish new biodiversity conservation areas including eroded and infertile areas. There have been deliberate initiatives by the government and donors to rehabilitate, restore and promote the recovery of the degraded ecosystems in Ethiopia (EBI, 2015). Towards arresting biodiversity degradation, a number of national, regional and district level programs were established including the formulation of the National Environmental Forest and Climate Change Commission (NEFCCC) which is directly accountable to the prime minister's Office, and the Environmental Protection Offices (EPO) in all Districts of the coutry. Other programs are the Sustainable Land Management (SLM) project, DRDI project, the CRGE GIZ project, REDD+ project, FARM-AFRICA, and the Agro-forestry Program (AFP) are some to mention are all projects and programs aiming at reducing land degradation in rapidly deteriorating areas through physical soil conservation measures such as afforestation, appropriate cultivation methods, control of run-off by contour band construction and planting vegetation in the river beds (Dereje Mosissa and Ashafi Mohammed 2019).

In Benishangul Gumuz Regional State of Ethiopia there are many preserved areas delineated by different organization/institutions such as Bureau of Environment, Land Administration and Investment (BoEFLAI), Bureau of Agriculture, Livestock and Rural Development (RBD), FARM AFRICA and Ethiopian Biodiversity Institute. The present situations in preserved areas indicate that they face enforcement and administration inefficiency towards handling exploitation pressures from local communities surrounding the protected areas (EBI, 2015). This is due to the fact that protected areas are the only areas that hold the entire source of livelihoods for the surrounding rural communities hence subjects the protected areas to an intensive reliance and dependence on the resources for sustaining their livelihoods. In line with weaknesses and deficiencies of the existing command and control measures in place, there has been an experienced rampant increase of unsustainable land-uses and other human activities in the areas.

Moreover, the virgin areas attracted many human activities including farming, house building (timber, building poles, thatch grass, ropes etc.), tree felling for fuel wood and farm expansion, and sporadic and massive grazing of livestock. Literatures suggest successful conservation constrains such as over extraction of the available resources, unsustainable land uses and poor institutional framework which exist along the resettlement process have made the resettlement process unsustainable.

In contrast to the prevailing situation in protected areas of Benishangul Gumuz Region, various approaches of environmental management measures have been employed to protect the natural resources and ensure sustainable livelihoods in the area. Traditional environmental management approach namely command and control measures has been practiced unsuccessfully, whereby enacted legislations, policies and regulations in place provided little control on existing rapid human activities and unsustainable land uses. Equally, the measures implicate minimum legal measures against the offenders on various issues mentioned in the district environmental protection bylaws due to poor and weak institutional framework. Meanwhile, valuing of socio-economic incentives approach of biodiversity management has not been widely used in the area and were in place with little knowledge and information on the roles of socio-economic importance towards sustainable biodiversity conservation of rural areas, hence the rationale of undertaking this study.

\section{Problem statement}

Despite the widely known merits and challenges of socio-economic approach of natural resource management and biodiversity conservation, little remains to be known on the roles of socioeconomic approaches towards sustainable biodiversity conservation of rural areas. The available literatures substantiate the existing wide understanding of the significant merits of socioeconomic incentives measures over command and control measures of biodiversity management measures (UNEP, 2004). It is further asserted that one of the socioeconomic significances is its leastcost efficient means of achieving biodiversity conservation objectives as they drive up the cost of environmentally harmful social, economic and livelihoods activities and increase the returns from conservation activities (UNEP, 2008). This study was an attempt to explore the little known roles of socio-economy towards influencing sustainable biodiversity conservation in rural areas of Assosa and Bambasi Districts, Benishangul Gumuz Regional State, Ethiopia.

\section{Objectives}

\section{General Objective}

- The general objective of the assessment is to investigate and map the important biodiversity and biocultural hotspot areas and to evaluate their socio-economic importance of the project intervention woredas and produce road map to guide decision-making for their sustainable conservation and use. 


\section{Specific Objectives}

- Analyze potential social, economic, ecological and bio-cultural benefits of the selected biodiversity hotspot areas to the local communities

- Assess the flora and fauna of important biodiversity hotspot and bio-cultural sites

- Demarcate and map the areas using GPS or other relevant tools

\section{Materials and Methods}

\section{Description of the Study Area}

\section{Bambasi District}

\section{Location}

The study was conducted in Benishangul-Gumuz regional state, in Bambasi Woreda, which is one of the twenty Woredas of the region. Bambasi Woreda is found $45 \mathrm{~km}$ far from Asossa town which is the capital city of the region. It is located in the southern part of the region between $09^{\circ} 47^{\prime}$ North latitude and $34^{\circ} 47^{\prime}$ East longitude (Figure 3).The Woreda is bordered by Oromia regional state and Maokomo special Woreda in the south and south west and, AsossaWoreda in the west and Oda Buldegelu Woreda in the north east.

Administratively, the Woreda is divided into 38 kebeles. 19 kebeles are inhabited by indigenous people, 17 kebeles are settled areas created during the Dreg regime and 2 kebeles are under the municipality of Bambasi town.

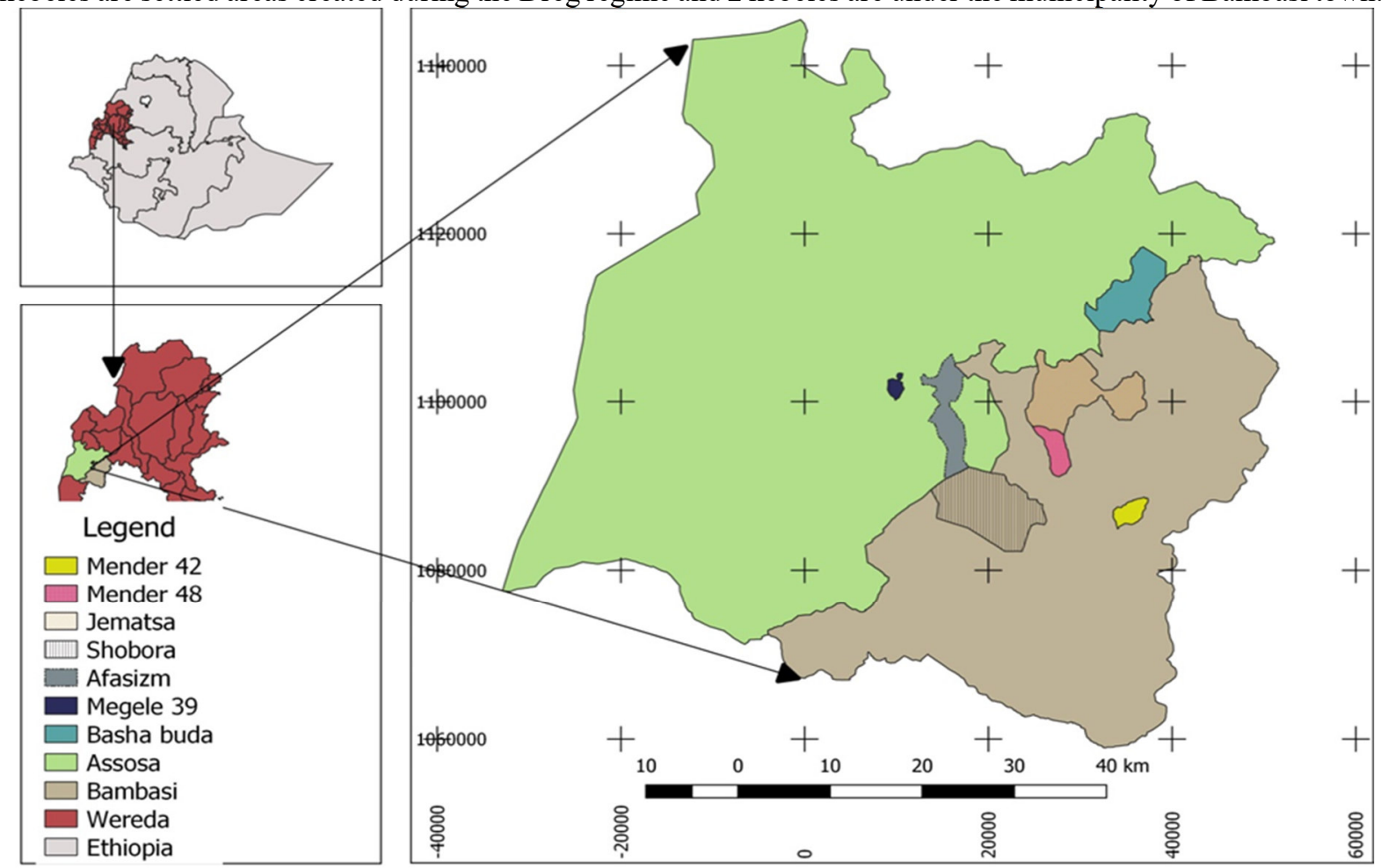

Figure 1: Map of the study area

\subsubsection{Population}

Based on CSA (2007) data, the total population of the Bambasi Woreda is about 70,350 people. The peoples found in this Woreda are composed of a variety of ethnic groups including Berta, Amhara, Oromo, and Tigre. There are also refugees from South Sudan in the woreda. In 2014 the total number of households is 12,539 of which 11,912 were male headed and 627 were female headed. Their livelihood structure is mainly depending on agriculture and traditional gold mining.

\subsubsection{Land use and Farming System}

The Woreda covers an area 472,817 hectares, of which 221,016 hectares are used for cultivation but now a day only 72,379 hectares are cultivated land, 10,000 hectares are pastureland, 63,756 hectares are non-cultivated land and 174,820 hectares are forest area, 1,200 hectares are mountain area, 1,797 hectares are irrigation area, 228 hectares are perennial crop area. The major food crops or cereals grown in the area are maize, sorghum and teff. Oil crops and others crops are also produced in the area. The average land holding is 4.65 hectares per household.

\subsubsection{Climate}

Climate data from the nearest meteorological stations Amba 16 (only rainfall, from 2005-2018) was extracted and presented in Figures 15 and the woreda is located at $9^{\circ} 57^{\prime} 12.4^{\prime \prime} \mathrm{N}$ Latitude and $34^{\circ} 39^{\prime} 21.7^{\prime \prime}$ E Longitude, with 
an altitude of 1554 m.a.s.l.

The average annual rainfall is $1381.42 \mathrm{~mm}$, while the mean annual maximum temperature is $28.37^{\circ} \mathrm{C}$. The area is characterized by unimodal rainfall distribution with the rainy season extends from March to November and one distinct short dry season extending from December to February (BWAO). Typically during the onset of the main rainy season, the first two months receive small amount and gradually reach to its peak in August. More than $55 \%$ of the mean annual rainfall falls from June to August.

The mean maximum monthly temperature is about $28.37^{\circ} \mathrm{C}$. Mean maximum monthly temperature reaches to its peak during March followed by April and February, with a temperature of $32.69^{\circ} \mathrm{C}, 32.05^{\circ} \mathrm{C}$ and $31.96^{\circ} \mathrm{C}$, respectively; whereas, the lowest mean minimum monthly temperature occurs during December with a temperature of $13.28^{\circ} \mathrm{C}$. This climate diagram of Bambasi Woreda shows water stress in January, February and November, and excess water in May, June, July August and September.

\subsubsection{Assosa District}

Assosa is one of the 20 woredas in the Benishangul-Gumuz Region of Ethiopia. Part of the Asosa Zone, it is bordered by Kurmuk and Komesha in the north, by Menge in the northeast, by Oda Buldigilu in the east, by Bambasi in the southeast, by Mao-Komo special woreda in the south and by Sudan in the west. Asosa Wereda has a latitude and longitude of $10^{\circ} 04^{\prime} \mathrm{N} 34^{\circ} 31^{\prime} \mathrm{E}$, with an elevation of 1570 meters (Figure 1).

The annual temperature of the areas varies and the daily mean temperature $22^{\circ} \mathrm{C}$ and the precipitation recorded at the meteorological station at Assosa is $237 \mathrm{~mm}$. The area has warm temperature at March and the lowest at July. Assosa district experiences extreme seasonal variation in monthly rainfall. The rainy period of the year lasts for 7.8 months, from March 23 to November 17, with a sliding 31-day rainfall of at least 0.5 inches. The most rain falls during the 31 days centered around August 11, with an average total accumulation of 8.6 inches. The rainless period of the year lasts for 4.2 months, from November 17 to March 23. The least rain falls around January 4, with an average total accumulation of 0.1 inches.

The 2007 national census reported a total population for this woreda of 104,147, of whom 52,968 were men and 51,179 were women; 24,214 or $23.25 \%$ of its population were urban dwellers. The majority of the inhabitants said they were Moslem, with $63.27 \%$ of the population reporting they observed this belief, while $31.18 \%$ of the population practised Ethiopian Orthodox Christianity, and 5.23\% were Protestant.

Based on figures from the Central Statistical Agency in 2005, this woreda has an estimated total population of 102,732 , of whom 53,340 are men and 49,392 are women; 20,226 or $19.69 \%$ of the population are urban dwellers. With an estimated area of 1,991.41 square kilometers, Asosa has a population density of 51.6 people per square kilometer which is greater than the Zone average of 19.95 (CSA, 2007).

\subsubsection{Anbessa Forest}

Anbessa forest is bordered by both Assosa and Bambasi districts of the Benshangul Gumuz National Regional State. It is located at $9^{\circ} 55^{\prime} 40.8^{\prime \prime} \mathrm{N}$ Latitude in the north to $9^{\circ} 53^{\prime} 24.3^{\prime \prime} \mathrm{N}$ Latitude in the south and around $34^{\circ} 50^{\prime}$ $55.3^{\prime \prime}$ to $34^{\circ} 39^{\prime} 09.0^{\prime \prime}$ E Longitude in the east and west, respectively. The forest is very narrow from north to south, while it is wide east - west ward, which reach near to Dabus River in the east. The main asphalt road from Addis Ababa (Bambasi) to Asossa crosses the forest around the western part. Anbessa forest is found surounded by six Kebele administratives namely: Amba 16, Jematsa, Garabiche Welega, Sonka, Mender 44, Mender 47, Meder 48, Shobora, Afasizm, and Megele 39 (Figure 2). According to the information from the local communities, the forest is said to be stretched from Dabus River in the east, to Ethio-Sudan border in the west.

The eastern part, which goes to Dabus River, is called Sitsa, the middle part is called Anbessa, and the western part, which extends to Ethio-Sudan border, is called Penshuba forest. The total area of the Anbessa forest is estimated to be 50,213 hectares. 


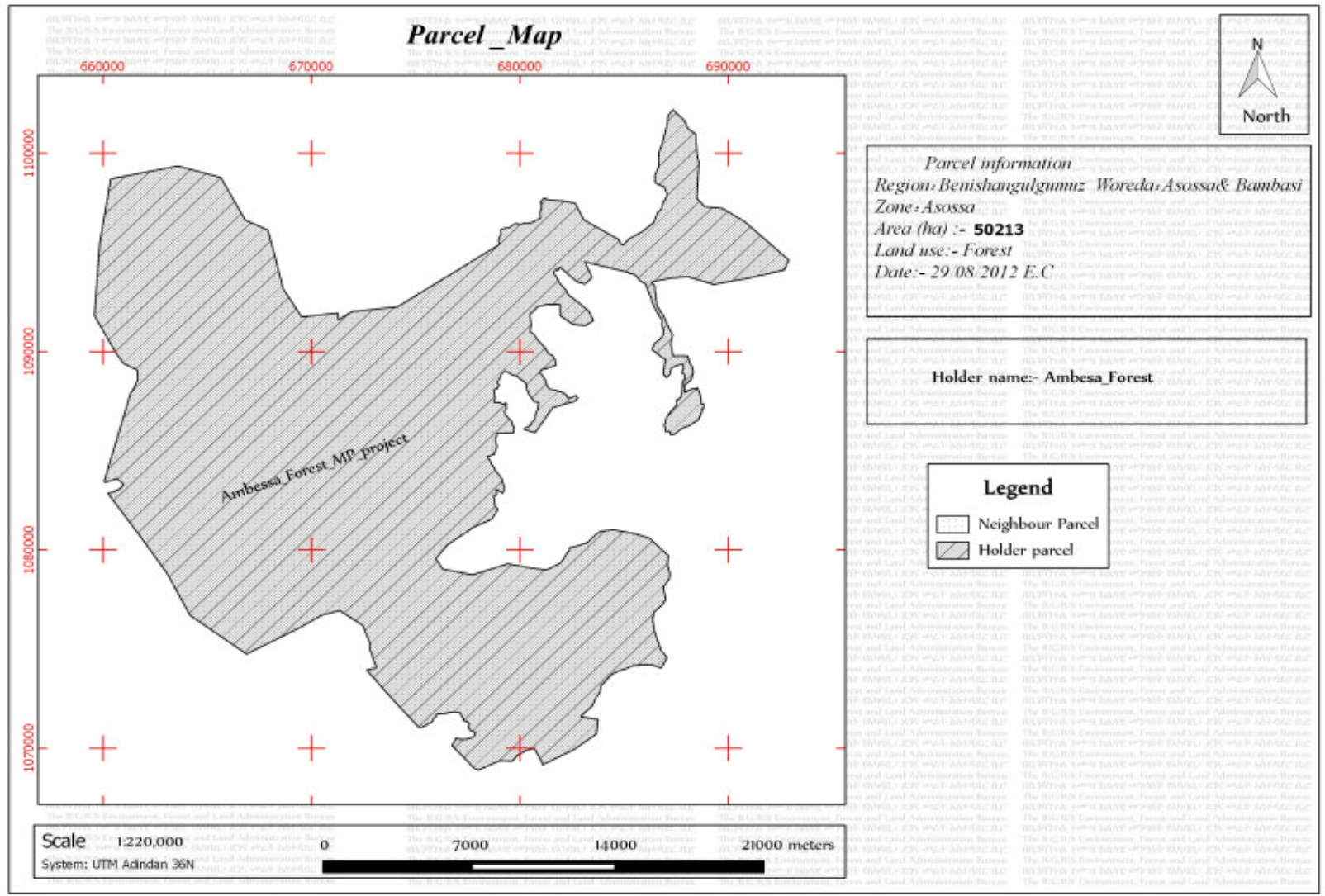

Figure 2: Map of Anbessa forest

The topography of Anbessa forest is very flat. Except for a few hills in the western part of the forest, near the main Addis Ababa - Asossa road, the rest of the forest is flat wooded grass land with very small slope variation. The elevation ranges from 1292 to 1563 m.a.s.l. with the highest peak being to the western side, while the lowest area is to the eastern side around Selga River with a total elevation variation of only 271 meters.

Anbessa forest is found in the Blue Nile river basin. There are a number of big and small rives which are tributaries of Blue Nile, such as Afa, Selga, Shosha, Mutsa, Nifiro, Abakidi, Eshama, Chilonya and many small streams which pass through or near by the forest. The Assosa-Bambasi area has many small creeks and rivers forming an extensive network of permanent water courses. However there are wetlands in some parts and during the rainy season some depressions fill with precipitation water, forming temporary or even permanent pools.

\subsubsection{Mender-42 Forest}

Mender- 42 forest is bordered by both Mender- 42 and Mender- 55 kebeles Bambasi District. It is located at $9^{\circ} 47^{\prime}$ $59.86^{\prime \prime} \mathrm{N}$ Latitude in the north to $9^{\circ} 48^{\prime} 05.30^{\prime \prime} \mathrm{N}$ Latitude in the south and around $34^{\circ} 45^{\prime} 23.99^{\prime \prime}$ to $34^{\circ} 45^{\prime} 09.77^{\prime \prime}$ E Longitude in the east and west, respectively. The forest is longer from north to south, while it is wide east - west ward, which reach near to two streams in the east-west. The road detaching from the main all weather road from Bambasi to Mender-42 crosses the forest east-west. Mender-42 forest is found surrounded by three Kebele administratives namely: Mender-42, Womba and Mender-55 (Figure 3). According to the information from the local communities, the forest is said to be used by refugees and other kebeles which are not its borders. The total area of the Mender- 42 forest is estimated to be 210 hectares. 


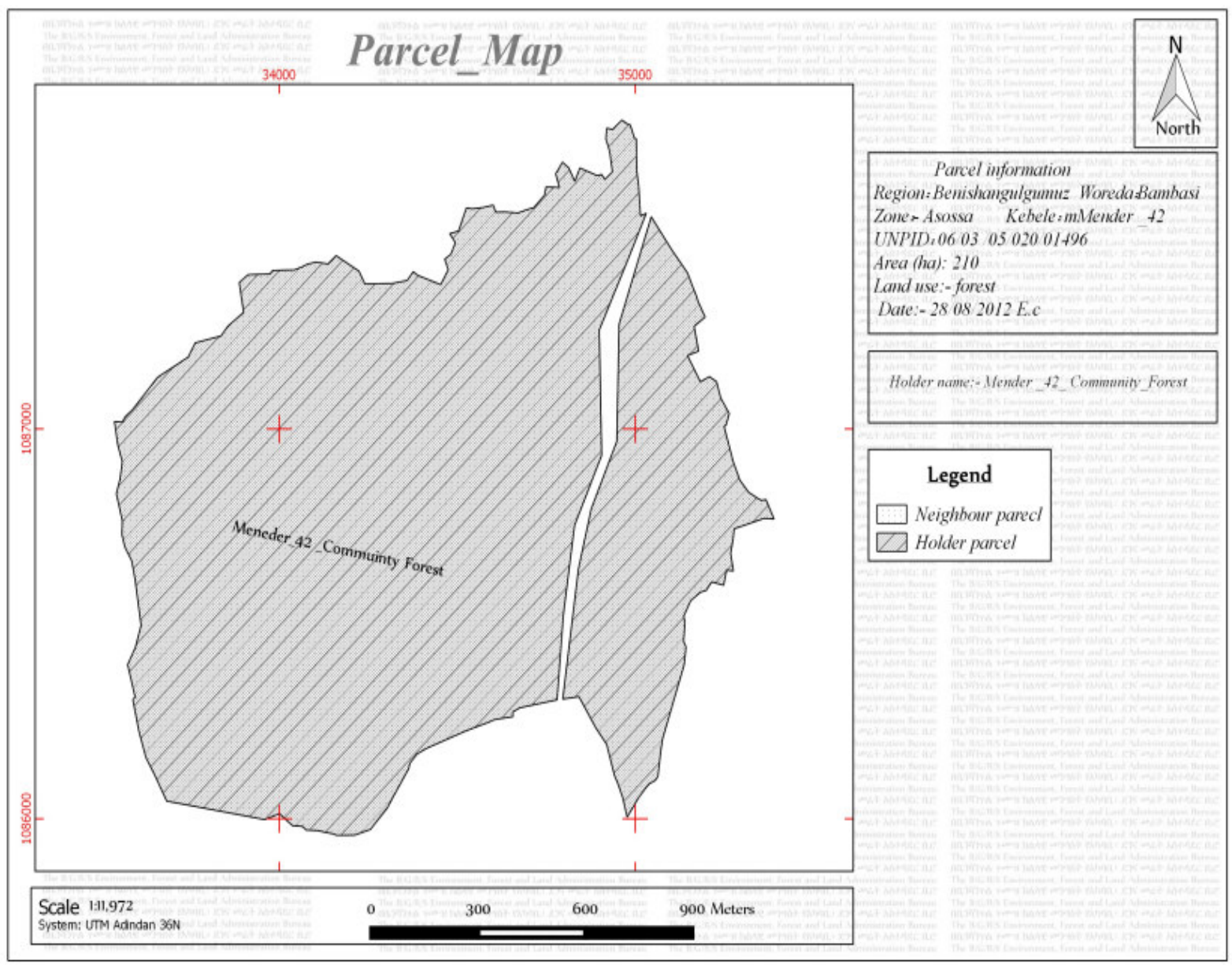

Figure 3: Map of Mender-42 forest

The topography of Mender- 42 forest is very flat. Except for a few hills the center of the forest, the rest of the forest is flat wooded grass land with very small slope variation. The elevation ranges from 1376 to 1449 m.a.s.l. with the highest peak being at the center of the forest, while the lowest area is to the north side around Checha River with a total elevation variation of only 73 meters.

The Bambasi area has many small creeks and rivers forming an extensive network of permanent water courses. However there are wetlands in some parts and during the rainy season some depressions fill with precipitation water, forming temporary or even permanent pools.

\subsubsection{Kolkis Forest}

Kolkis forest is majorly bordered by both Basha Buda and Mender-55 kebeles of Assosa and Bambasi District. It is located at $10^{\circ} 00^{\prime} 48.57^{\prime \prime} \mathrm{N}$ Latitude in the north $34^{\circ} 43^{\prime} 58.99^{\prime \prime}$ E Longitude in the east , respectively. The forest is longer from east to west, while it is longer to east - west ward, which streachs Anbessa Forest. There is no any road to access the forest area except some seasonal roads by visiting farmers. Kolkis forest is found surrounded by mainly three Kebele administratives namely: Basha Buda, Abu Mutsa and Mender-55 (Figure 4). The total area of the Kolkis forest is estimated to be 200 hectares. 


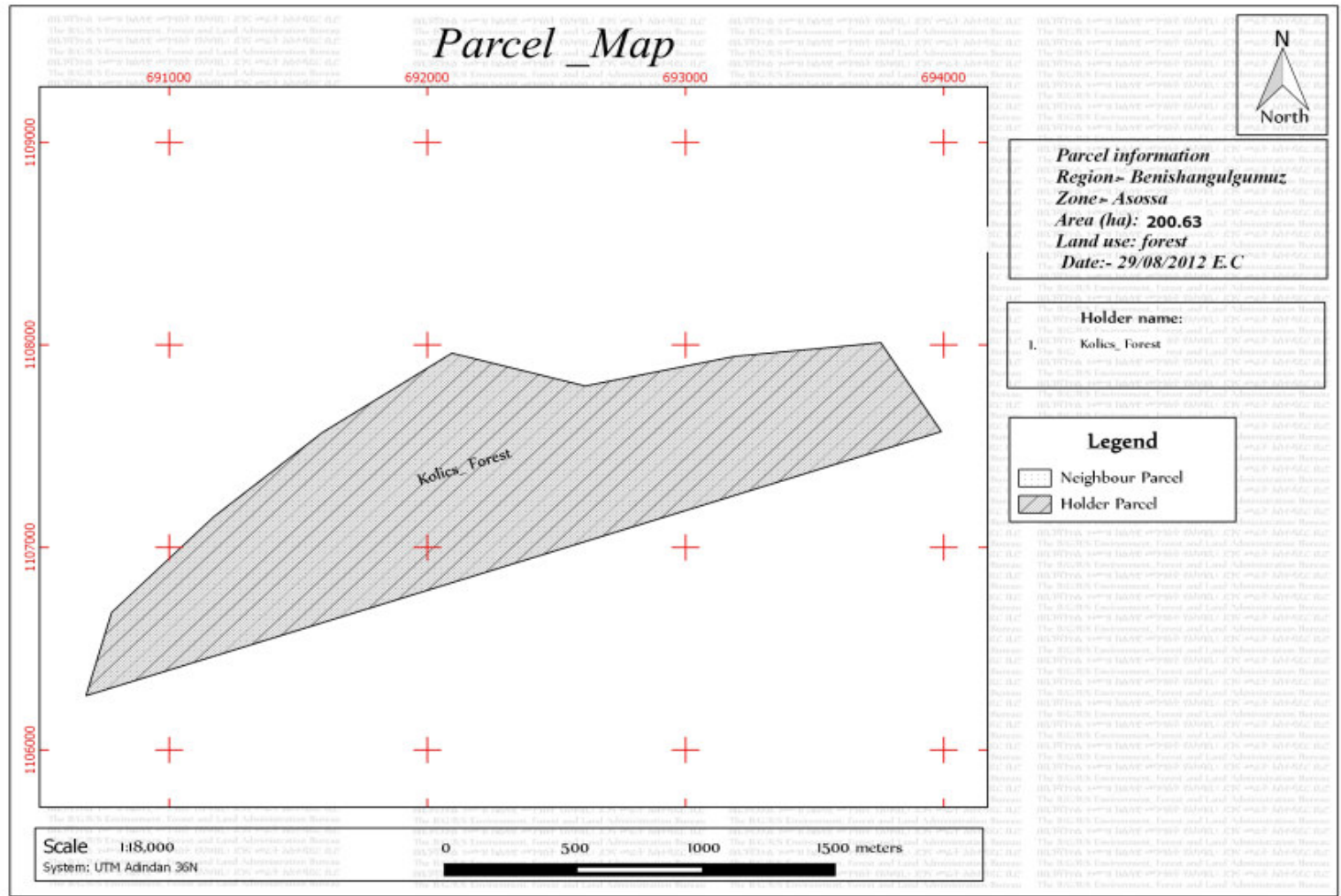

Figure 4: Map of Kolkis forest

The topography of Kolkis forest is hilly with large plateaus on the top and with some flat areas to north-south. Except for a few hills on the top of the forest, the rest of the flattened top is covered by very large trees with wooded grass. The elevation ranges from 1341 to 1372 m.a.s.l. with the highest peak being at the center of the forest, while the lowest area is to the south.

\subsection{Research Methodology}

\subsubsection{Valuation of biodiversity}

There are different dimensions or methods by which the socio-economic importance of biodiversity can be estimated. According to Costanza et al, 1995 these methods can be divided in to three.

i. $\quad$ Stated or Revealed Preference Methods

Stated preference relies on survey approaches through which people provide estimates of their willingness-to-pay (or willingness-to-accept) for the protection of biodiversity where this can be shown to contribute directly or indirectly to their quality of life. Instances would be the association with outdoor recreation, or other indirect uses or even non-uses such as a pure appreciation of wildlife or biodiversity. Revealed preference achieves the same objective where this utility can be demonstrated through associated market mechanisms. Examples here would be where property prices capture proximity to an attractive natural landscape, or the costs of travel to a recreational area with high biodiversity.

\section{ii. $\quad$ Production Function Approach}

In the production function approach, biodiversity forms an input to an economic process. This requires some detective work to attribute that proportion of the value of product which is contributed by ecosystem services. For instance, although a single type of crop or tree might have value as food or timber, its growth depends on a variety of ecosystem services performed by various species. Similarly, ecosystem services will enhance forage production on a farm and this will contribute to the weight gain of grazing animals and a higher final price.

\section{iii. Cost-based Approaches}

Cost-based approaches do not provide estimates of utility, but rather provide a demonstration of the value of biodiversity through a surrogate product. For example:

- 'Replacement cost' examines the amount that would need to be spent to replace the ecosystem services that are provided by biodiversity. Examples could include hand pollination or the use of fertilizers or pesticides.

- 'Damage avoided' looks at the cost of adverse outcomes which could arise in the absence of a functioning ecosystem. This approach could be used to quantify the external costs of activities which ignore or damage biodiversity of which the health impacts of pesticides would be one example. 
- 'Preventive expenditure' is related to the above in that it calculates how much would need to be spent to avoid such costs. One example that follows on from the above would be the additional water purification needed to remove pesticide residue.

\subsubsection{Methods adopted}

In this research, the production function method is used most regularly, albeit rather crudely given the range of ecosystem services which must be considered here. Ideally, it would be necessary to attribute that component of value which is contributed by biodiversity. It is also necessary to avoid double-counting or over-estimating the costs that are truly attributable to biodiversity. For example, the above examples of the replacement cost posed by the purchase costs of pesticides can be added to the social costs of their potentially adverse health impacts as an instance of the cost of lost ecosystem services. However, the costs cannot simply be added to that of the preventative expenditure which must be made on water purification that might remove toxic pesticide residue. Valuation, of any kind, is not straightforward. Production function or cost-based methods are challenged by the limited scientific understanding of ecosystem functions, including in areas that are highly important to primary production such as soils and the oceans. Imperfect information also applies to the use of stated preference tools based on surveys in that most people have a very limited understanding of biodiversity even where they do value its outcomes.

\subsection{Research Approach}

This research is both an inventory and a case study research type of deductive nature. Deductive approach begins with the theoretical statements which outlines the logical connection among concepts/statements and moves towards concrete empirical evidence. In this research, abstract concept about the contribution of forest resources of protected areas for rural people's livelihood will first developed based on previous professional research work and thereafter, attempted to support or not the theoretical statements by the collected data and results from empirical data in a wide variety of farmers.

Based on the audience and use of research, this is an applied research. Applied research designed to offer a practical solution to a concrete problem or address the immediate and specific needs of clinicians or practioners (Neuman, 2006). It relies on a quick, small-scale study that provides practical results that people can use in the short term. It develops a long term general understanding about biodiversity and its role in their livelihoods and results can be used by general practioners, farmers, NGOs/CSOs for further improvements in this sector. The major research approaches used for data collection are exploratory and explanatory. The research explores the flora and founa and the degree of dependency of farmers on forest resources for rural livelihood in the study area and explains the problems and opportunities regarding its conservation and sustainability use.

\subsection{Research Process/design}

The research started by brining thoughts on identifying the problem areas based on literature reviews and preparing scientific research proposal based on the concept developed. During the preparation of proposal, various ideas about the topic will be taken from different forest experts and professionals by direct contact, telephone conversation and e-mails. Series of discussion with professionals encouraged critical thinking on concepts used in this research. Colleagues and other professionals also provided valuable inputs for preparing concept during informal discussions. Several discussions with various regional as well as district level line sectors and stakeholders were carried out. HHs survey questionnaires and checklist for focus group discussion, and key informant survey was developed and finalized after the discussion with research team and experts.

Discussion with local facilitators and stakeholders were helped planning of the field work. Pre-field visit was carried out and questionnaire and check lists are going to be pre-tested before the actual field work and corrected for actual field survey. Data were collected using various methods after consultation with all the professionals. After completing fieldwork, firsthand information was discussed with local leaders, district level stakeholders and experts.

Post-field visit was also carried out for taking some missing data. Compilation of data, analysis of the data, reporting of the results and discussions with the all stakeholders would lead to the conclusions and recommendations and final document preparation.

Respondent households from each kebeles were randomly selected from detailed households' lists (with names of household head and assigned numbers for use in random sampling). In polygamous unions, households were listed according to the wife's name and each considered a separate household. The sample size for each study kebele and location was determined using the most recent national census data and applying the method by $\mathrm{O}$. Mugenda and A. Mugenda, 1999. In total 151 households were selected for the study. Socio-demographic data were collected using structured and semi-structured questionnaires.

To improve the confidence of the respondents and quality of data, local trained research assistants (DAs') conversant with local languages interviewed the respondents in the presence of kebele elders. In most cases, the head of the house hold was interviewed and, in the absence, the wife or the eldest son was interviewed. The 
following socioeconomic data were collected from each household: sources of cash income, resources endowment (land size, livestock size, and physical assets), literacy levels (education level), household size, resident years, ethnicity, and distance from the forest. Forest utilization data included consumption patterns of forest products (including their sources, average quantity per month, and household monthly consumption), collection and type of forest products, and other associated information.

The information obtained from respondents was triangulated using key informants and focus group discussions. The market survey captured the prices of various forest products traded in local markets and prices used to value the household forest-product consumption and determined monetary contribution of the forest products to the total household income.

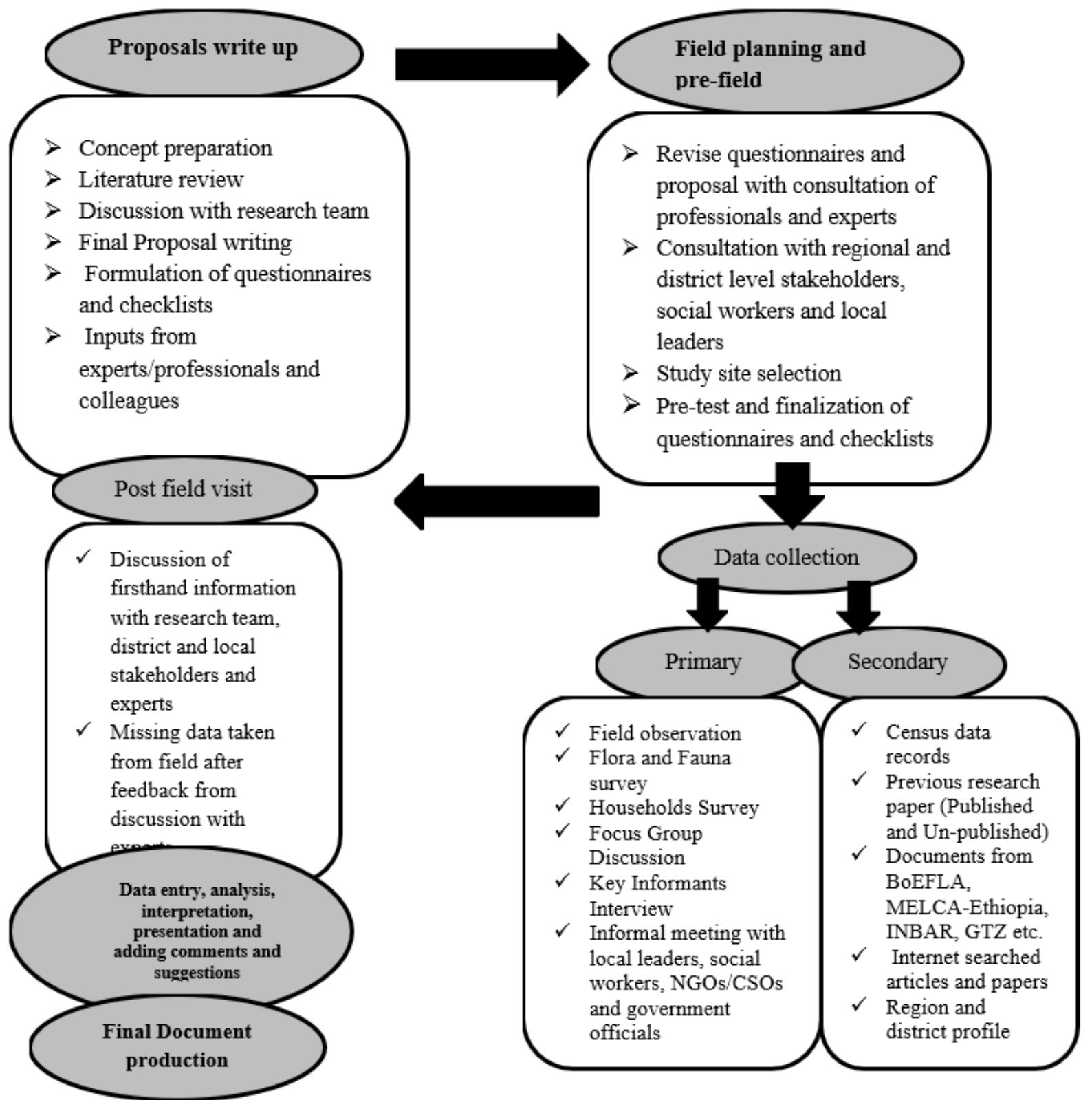

Figure 5: Overall research process

\subsection{Research Site Selection}

This research was conducted in selected kebeles of both Assosa and Babasi district in the central and southern areas of Assosa Zone.

\subsubsection{Consultation with experts}

Before selecting the site, basic information will be collected from different parts of the country where farmers are involved in forest based family occupation at different level. During that time, several meetings and informal discussion will be carried out with the professionals of local Non-government Organizations (NGOs), Environment 
Conservation Associations, International Network for Bamboo and Rattan (INBAR), German Technical Cooperation (GTZ), EBI-Assosa Center and MELCA-Ethiopia' who are working in the biodiversity conservation and have more knowledge and idea about situation of forest resource use, conservation, management and marketing. Based on the objective of the research and discussions with experts, Assosa and Bambasi districts will be selected as a study area for this research.

\subsubsection{Criteria for site selection}

The majority of the community residing in these areas depends on the forest resources of the area, along with agriculture, as the main income source. The peoples in the area live on the use of forest resources for ages. On the other hand, series of studies and researches about traditional use of forest resources for socio-economics of rural people are carried out in other areas of the country. Although, this site is very near from the regions capital city, Assosa, the research about the households' tradition about forest resource use and its importance for their subsistence livelihood is still lacking. We cannot find detailed information and research articles about the dependency of the household of the study area on biodiversity in general and forest resources in particular. After kebeles selection, continuous discussion will be carried out with officials of Assosa and Bambasi districts and seven kebeles are going to be identified for conducting this research which met the following criteria on the basis of their experience and observations.

$\checkmark$ Kebeles encompassing high biodiversity hot spot areas and known to have important habitats $f$

$\checkmark \quad$ Kebeles with majority of the households depend on mixed agriculture as a small scale business in each kebeles

$\checkmark$ Households with heterogeneous structures in terms of ethnicity, economic class etc.

$\checkmark$ Kebeles experienced forest conservation practices and its sustainable use

\subsection{Data Collection Methods/Processes}

For the purpose of this research, an approach which uses quantitative data in conjunction with qualitative data was considered to be the most appropriate. Qualitative data can help to assess the validity of analysis based on quantitative data and possibly provide seemingly contradictory findings to quantitative data, revealing important issues that need further exploration. While qualitative methods assist local people to assess and communicate information about their situation, in-depth information about the respondents' special needs, resources and constraints can be gathered (FAO, 2004).

Before starting the field work, basic information about the research site will be gathered by consulting with the officials of Assosa and Bambasi districts, local leaders, community workers etc. The purposes, methods and schedule about the research work were well informed and described to them and also requested to participate and cooperate during the whole research work. Kebele forest protection Committees (KFPC), NGOs/CSOs and professionals will also be pre-informed about the research work that made easy for gathering more information about the research.

Primary data collection method is the best source of information collection. From this method, firsthand experience of the respondents could be recorded. Clearly demarcated interest could be identified based on age, style of living, sex, education and other divisions in society. There are several methods of primary data collection. In this research, some survey tools will be used which is discussed below.

Secondary data is needed for investigating the local context by providing the necessary background information. Common sources of secondary data include censuses, large surveys, and organizational records, Flora and Fauna data, Meteorological records. They are qualitative and quantitative.

In this research, the relevant qualitative data were taken from BoEFLU records and minutes, and quantitative information were taken from Central Statistics Agency (CSA), and district profile, previous published and unpublished research papers, national and international journals, documents from MELCA-Ethiopia, EFCCC, BoELAI, NGOs/CSOs such as Assosa Environment Protection Association, INBAR, GTZ, Farm Africa and some articles and papers from internet.

\subsubsection{Flora and Fauna survey}

Depending on pre survey of the area and assumed species diversity a total of $8,6,5$ transects were laid for Anbessa, Kolkis and Mender-42 forests respectively with the plots varying from 5-8 plots. The plots were established along transects and the interval between plots was $100 \mathrm{~m}$. A total of 111 plots (46 plots for Anbessa, 34 plots for Kolkis and 31 plots for Mender-42 forests) were laid to census vegetation data.

Parallel line transects will be laid out based on the topographical shape of the land and based on the area coverage and this was $300 \mathrm{~m}$ distance apart from one another in left and right. Along each transect line $10 \mathrm{~m} \times 10 \mathrm{~m}$ $(100 \mathrm{~m} 2)$ sample quadrates was plotted systematically at $100 \mathrm{~m}$ distance from one plot to the other interval and all the species encounter was recorded by using the species recording sheet prepared to record all the species encountered in a sampled plots along the transects laid. (Tamene Yohanse, 2016). 


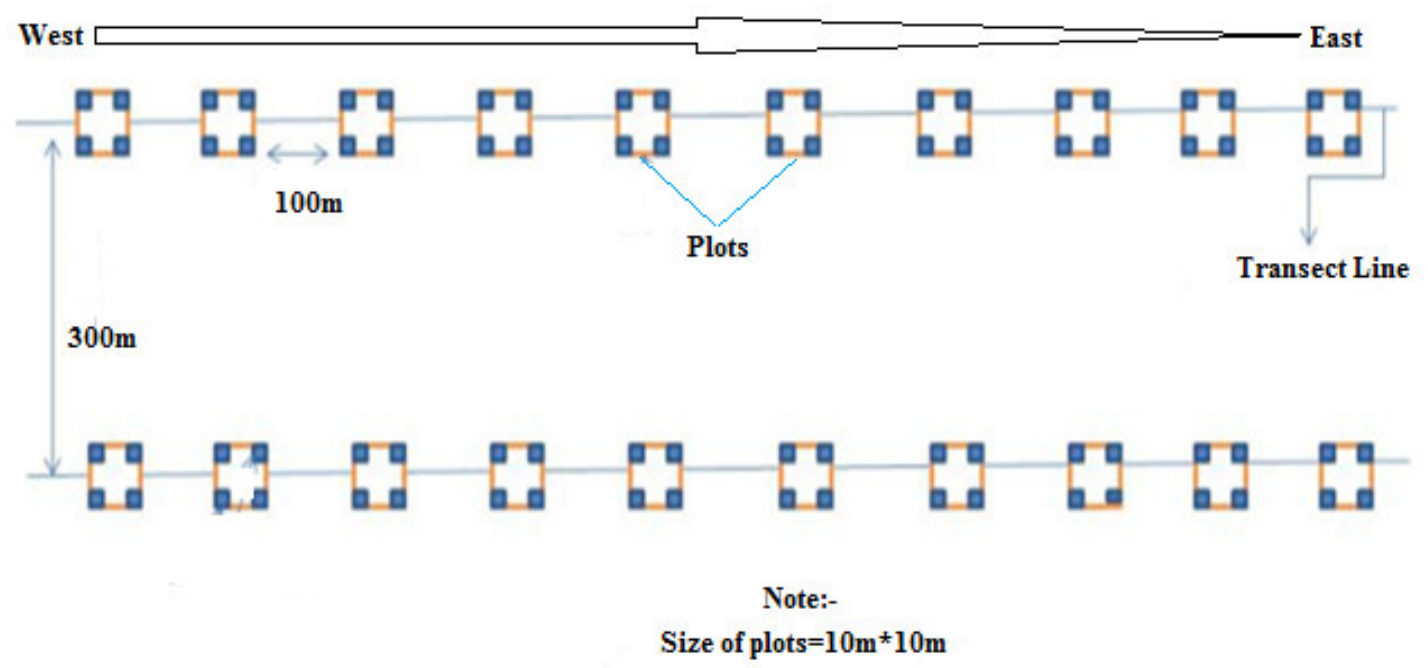

Figure 6: Schematic representation of transects laid and plots sampled

\subsubsection{Household survey}

\subsubsection{Sample Size Determination}

The information from local administration offices of seven kebeles selected indicated that there are 1895 total households in both Bambasi and Assosa Districts. From among different methods, the sample size determination the one which is developed by Carvalh (1984).was used by the researchers. The method is presented in table below. The HHs size of the study in seven kebeles is 1895 . So the range lies between 1201-2100, according to Carvalho's sample size determination indicated in Table 1, Thus taking to account a small population size variance and the cost of taking samples and time consuming for huge sample size large sample size was applied in according with the given population size. Therefore the sample size selected for the study under consideration was 151 .

Table 1: Sample Size Determination

\begin{tabular}{llll}
\hline Population Size & Low & Medium & High \\
\hline $51-90$ & 5 & 13 & 20 \\
$91-150$ & 8 & 20 & 32 \\
$151-280$ & 13 & 32 & 50 \\
$281-500$ & 20 & 50 & 80 \\
$501-1200$ & 32 & 80 & 125 \\
$1201-2100$ & 39 & 100 & 150 \\
$2101-3200$ & 50 & 125 & 200 \\
$3021-10000$ & 80 & 200 & 315 \\
\hline
\end{tabular}

(Source Carvalho 1984)

A semi-structured survey was conducted in the selected respondent (HHs) of the research site. Local level facilitators who have more knowledge about their locality and forest resource utilization, management and conservation and researcher himself was intensively involve in the whole survey. A total of $151 \mathrm{HHs}$ from seven kebele was selected for household survey. Direct (face-to-face) interview will be applied for information collection. The already developed questionnaire will be asked in in all selected kebeles. Both open-ended and close ended questions will be developed for collecting detailed information about the research topic.

\subsubsection{Direct observation}

During the research period, the researcher visited the respondents' house to house as well as in their community forest. The activities of users such as domestication of wild species, its management practices and present status of community forests in their private land and also in CF will be observed directly in the field by transect walk. Informal interviews and discussions at homestead and community meetings will also be made several times. This method will be useful to the researcher for both in-depth information collection and triangulation of information.

\subsubsection{Focus group discussion}

A focus group discussion (FGD) is a form of qualitative research in which a group of people talk freely and spontaneously about a certain topic. In FGD, Questions are asked in an interactive group setting where participants are free to talk with other group members. Its purpose is to obtain in-depth information on concepts, perceptions and ideas of a group. The idea is that group members discuss the topic among themselves, with guidance from the facilitator.

Based on the objective of the research, 4 FGDs (one women FGD, 3 mixed FGDs will be conducted in all the kebeles selected. Local facilitators and officials from kebele will help to organize all FGDs. For women FGD, 5 women and a total of 15 will be taken randomly. Similarly, equal number of participants (both male and female) 
will be selected for mixed FGDs and a total of 12 participants ( 6 male and 6 female) will be selected for each FGD. 3.8.5 Key informant interview

The key informant interview involves identifying different members of the community who are especially knowledgeable about a topic and asking them questions about their experiences working or living within a community. In this research, Key informant interviews will be taken from 6 respondents ( 2 from social workers, 2 from local leaders, 2 from traditional healers). The information about forest resource and their existing condition, market price, cost-benefit situation, their management practices, NGOs/CSOs and government initiatives in forest sector etc. will be discussed with the key informants. The information taken from key informants will be used for triangulation of HHs surveyed data.

\subsubsection{Post field visit}

After completing the field work, the first-hand information will be discussed with all stakeholders. A short postfield visit will be carried out for taking some missing information and clear about some confusion in the information collected during the main field work.

\subsection{Data Management}

The first-hand collected raw data was entered in statistical software called statistical package IBM SPSS version 21 (2013). When transferring the data from paper to computer it is important that the information is complete and that checks are made if the electronic copy is a faithful transcription of the originals. This strategy should avoid inherent bias. The backup file will be generated in order to avoid a loss of data. After managing the data, different statistical measurements will be used for the further interpretation according to the objective of the research.

\subsection{Data Analysis}

The collected field data were compiled and analyzed using the statistical package IBM SPSS version 21 (2013) and Microsoft Office Excel 2010. The household incomes were calculated without accounting for local labor costs because of substantial variation in costs for each activity and the possibility of multiple tasks by households (B. M. Campbell and M. Luckert, 2002). The household incomes were computed using the formulae (1) to (4) as shown below.

Household annual income $=($ forest Income + agriculture income + return to wealth + wage income $)$ :

$$
Y_{\text {tinc }}=\sum_{n=1}^{n}[\mathrm{Si}]
$$

Where $Y_{\text {tinc }}$ is total household income and $\mathrm{S} i$ is income source $I$.

Forest income $=($ fuel wood annual income + wild foods income + poles income + thatching grass income and forest grazing, etc):

$$
Y_{f}=\sum_{n=1}^{n}[\mathrm{FiP} i-(K i)],
$$

Where $Y f$ is total forest income, $F i$ is quantity of product collected $I, P i$ is market price of forest product $I$, and $K i$ is production costs of forest product $i$.

The value of forest grazing was estimated by substitute approach.

Crop income: this was summation of value of yield from various crops grown by a household less all costs of production. Total crop income was calculated as:

$$
Y_{c}=\sum_{n=1}^{n}[\mathrm{CiPi}-(K i)]
$$

Where $Y c$ is total crop income, $C i$ is yield of crop $I$, is market price of crop $I$, and $K i$ is production costs of crop $i$. Livestock income $=($ cattle sale income + goats income + sheep income + donkeys income + chicken income $)+$ income from livestock products that is

$$
Y_{l}=\sum_{n=1}^{n}[\mathrm{NiPi}-(K i)]+\sum_{n=1}^{n}[Q i P i-(K i)],
$$

where $Y l$ is total livestock income, $N i$ is number of livestock in category $I, Q i$ is quantity of product from livestock $I, P i$ is market price of livestock $I$, and $K i$ is cash costs of keeping livestock $i$, like pay for herder, costs of medicines, feeds.

Income from off-farm income/employment: this was the total value of earnings through hiring out of labour on other households' lands for agricultural or any other economic activity.

\subsubsection{Statistical Tests}

Socioeconomic data presents a challenge in a heterogeneous community where extreme income values from individual households are expected. Data was subjected to normality tests (box-plot, histogram). All the identified 
outliers in the data set were removed to conform to normal distribution. It was then that parametric tests (analysis of variance (ANOVA)) were applied (Y. H. Chan, 2005). In all statistical tests, $p \leq 0.05$ level of significance was used. Tests were conducted on socioeconomic characteristics, $\chi 2$ test being for association of locations and sources of forest products, wealth, education level, and ethnicity. Comparison of means and one-way ANOVA were used to test the difference on forest incomes, relative forest incomes on locations, ethnicity, and wealth class and separation of means undertaken using Tukey B.

\subsubsection{Measuring Forest Dependence}

The forest dependence was measured using the relative forest income. Relative forest income (RFI) was computed as a share of net forest income to total household income accounts derived from consumption and sale of forest environmental resources. This was derived as

$$
R F I=\frac{T F I}{T I},
$$

where TI is the total household income and TFI is total forest environmental income.

To test the level of forest dependence of income groups, sampled households were categorized into 3 income groups based on their level of total households income in Ethiopian birrs: Poor, 0-1500, Moderately Poor, 15002700 , and Rich, $>2701$. The categories were based on local conditions and do not reflect the general poverty levels in the study area and Ethiopia.

\section{Results and Discussion}

\section{Socioeconomic and Demographic Characteristics of Households}

The sex distribution of household heads showed that $73.6 \%(n=109)$ were males while $26.4 \%(n=39)$ were females. The mean age of household head was significantly different $(p<0.001)$ for female $(53.35 \pm 1.9)$ and maleheaded households $(47.56 \pm 1.2)$ (Figure 7). The majority of the respondents in the Mender-42, Mender-48 and Megele-39 location were immigrants/Settlers (Amhara, Tigrie or Oromo) (100\%) whereas the remaining respondents in Jemats, Shebora and Basha Buda were indigenous (Berta or Mao Komo) (Table 2).

Table 2: Socioeconomic and demographic characteristics of sampled households $(N=151)$

\begin{tabular}{|c|c|c|c|}
\hline Variables & & Frequency & Percent \\
\hline \multicolumn{4}{|l|}{ Sex } \\
\hline & Male & 109 & 73.6 \\
\hline & Female & 39 & 26.4 \\
\hline \multicolumn{4}{|c|}{ Educational } \\
\hline & Illiterate (no read \& write) & 65 & 43.9 \\
\hline & Read \& Write & 30 & 20.3 \\
\hline & 1-8 grade & 33 & 22.3 \\
\hline & $9-12+$ & 20 & 13.5 \\
\hline \multicolumn{4}{|l|}{ Ethnicity } \\
\hline & Bertha & 76 & 51.4 \\
\hline & Amhara & 38 & 25.7 \\
\hline & Oromo & 5 & 3.4 \\
\hline & Tigrie & 23 & 15.5 \\
\hline & Mao-Komo & 5 & 3.4 \\
\hline \multicolumn{4}{|c|}{ Marital status } \\
\hline & Married & 107 & 72.3 \\
\hline & Widowed & 28 & 18.9 \\
\hline & Divorced & 13 & 8.8 \\
\hline \multicolumn{4}{|c|}{ Occupation } \\
\hline & Farmer & 120 & 81.1 \\
\hline & Farmer \& Merchant & 19 & 12.8 \\
\hline & Student & 8 & 5.4 \\
\hline & Farmer \& Employee & 1 & 0.7 \\
\hline \multicolumn{4}{|l|}{ No. HHs } \\
\hline & $1-6 \mathrm{hhs}$ & 92 & 62 \\
\hline & $7+$ hhs & 56 & 38 \\
\hline
\end{tabular}

The majority of households were born in the current place of residence $(64.8 \%)$ and only about one-third (35.2\%) were not born in current place of residence. Majority of the households interviewed were those which cannot read and write (43.9\%). Results on the highest educational level attained by heads of households revealed that $22.3 \%$ have at least primary level of education, while $13.5 \%$ have attained secondary level of education and only $6.9 \%$ have diploma with the lowest $2.4 \%$ and $4.9 \%$ in Jematsa and Megele-39, respectively (Table 2). 


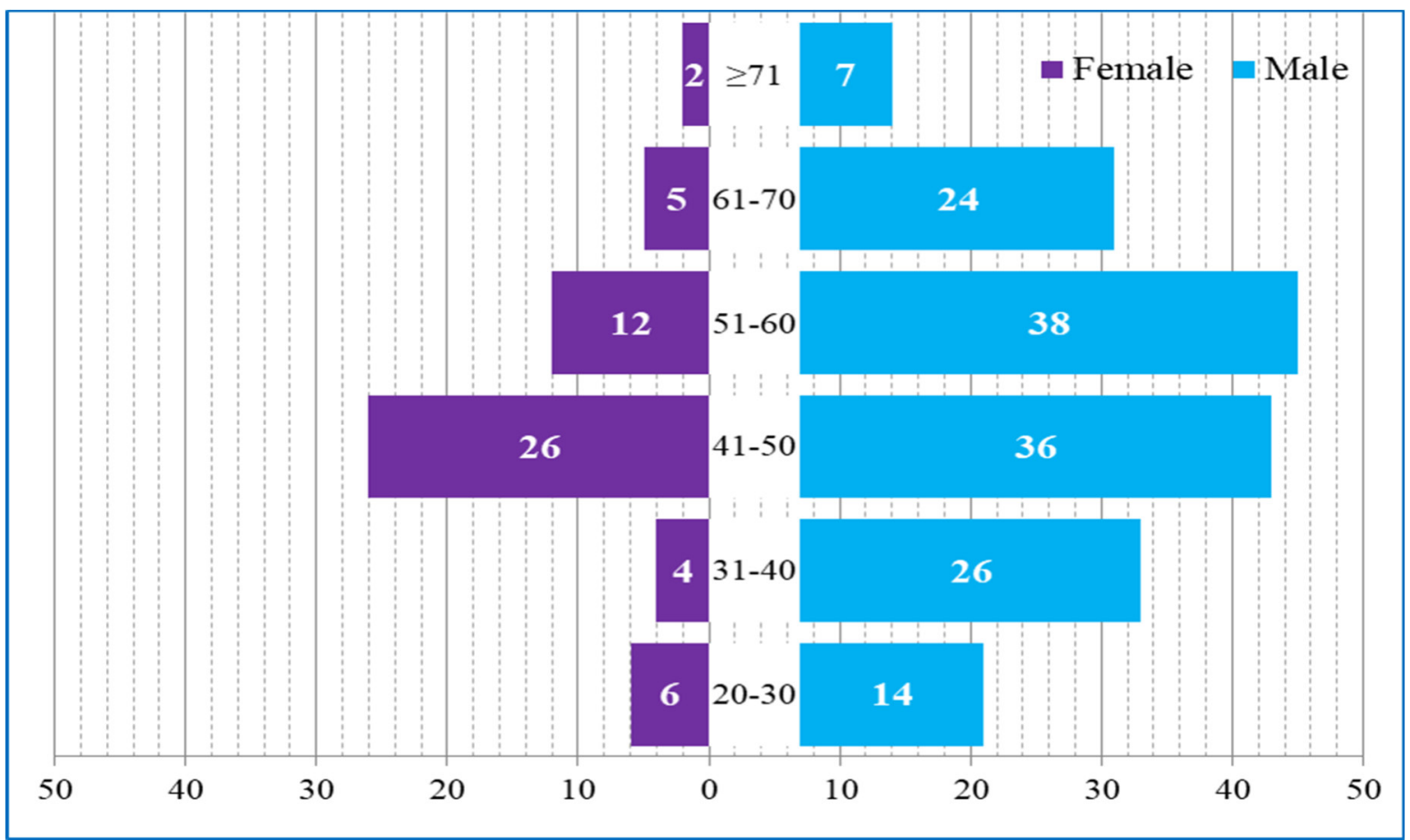

Figure 7: Age and Sex distribution of respondents in the study area

\section{Livelihood Activities of Households}

Most of the households $(90.5 \%)$ interviewed were farmers $(n=120)$ relying mostly on rain-fed agriculture and livestock keeping. Other livelihood activities were small scale retail business, wage employment, and sale of forest products. The total household income $((4,372)=5.10 ; p \leq 0.001)$ was significantly different across study location and between indigenous and Settler groups $((1,372)=7.82 ; p=0.05)$. The total household income in all kebeles except for Jematsa \& Shebora and Megele \& Basha Buda was significantly different. However, across these kebeles household income differed significantly (Table 3). Agricultural income was significantly different across all locations $((4,382)=2.55, p=0.05)$. Tukey B test separation of means showed that households in Mender-42 differed significantly from the households in other locations. However, agricultural household income in Shebora, Jematsa, Afasizm, Megele-39, and Basha Buda was not significantly different. In addition, income from sale of forest products was not significantly different across location $((4,72)=1.23 ; p=0.05)$ except for megele-39 and Basha Bua and between indigenous and nonindigenous groups $((1,75)=1.62 ; p=0.05)$ except for Megele-39.

Table 4: Mean separation and socioeconomic characteristics of respondents $(N=151)$

\begin{tabular}{|c|c|c|c|c|c|c|c|c|}
\hline Variables & Mender-42 & Mender-48 & Jematsa & Shobora & Afasizm & Megele-39 & Bashabuda & $\begin{array}{l}\text { Sig. } \\
\text { (LSD) }\end{array}$ \\
\hline \multicolumn{9}{|l|}{ Gender (HH) \% } \\
\hline Male & 73.3 & 85.4 & 67.2 & 72.0 & 62.6 & 83.4 & 75.0 & NS \\
\hline Female & 27.7 & 14.6 & 32.8 & 28.0 & 37.4 & 16.5 & 25.0 & NS \\
\hline \multicolumn{9}{|l|}{ Ethnicity (\%) } \\
\hline Indigenous & 0.0 & 0.0 & 100 & 100 & 97.5 & 0.0 & 100 & $0.05^{*}$ \\
\hline Settlers & 100 & 100 & 0.0 & 0.0 & 2.5 & 100 & 0.0 & $0.05^{*}$ \\
\hline \multicolumn{9}{|l|}{ Education level (\%) } \\
\hline No read \& write & 11.3 & 16.7 & 56.6 & 47.2 & 65.5 & 22.1 & 46.9 & $0.05^{*}$ \\
\hline Read \& Write & 66.7 & 60.4 & 60.4 & 62.7 & 49.5 & 87.9 & 52.3 & $0.05^{*}$ \\
\hline Primary $(1-8)$ & 49.0 & 42.4 & 34.8 & 39.7 & 29.6 & 51.8 & 25.6 & NS \\
\hline Secondary and above & 9.7 & 5.8 & 1.2 & 0.8 & 0.5 & 2.6 & 0.7 & NS \\
\hline \multicolumn{9}{|l|}{ HH size } \\
\hline Number & $5.3 \pm 3.6$ & $4.9 \pm 2.4$ & $9.0 \pm 2.4$ & $10.1 \pm 3.1$ & $9.8 \pm 2.6$ & $7.3 \pm 3.6$ & $8.9 \pm 3.0$ & $0.005^{*}$ \\
\hline \multirow{2}{*}{\multicolumn{9}{|c|}{ Land size and use }} \\
\hline & & & & & & & & \\
\hline Land size (Ha) & $2.5 \pm 1.2$ & $2.1 \pm 0.8$ & $12.9 \pm 4.5$ & $9.5 \pm 1.2$ & $10.9 \pm 6.5$ & $1.7 \pm 1.4$ & $15.9 \pm 8.5$ & $0.000^{* *}$ \\
\hline Natural forest & 0.0 & 0.0 & $5.4 \pm 0.3$ & $3.6 \pm 0.7$ & $1.4 \pm 0.3$ & 0.0 & $2.4 \pm 0.3$ & $0.001 *$ \\
\hline Planted forest & 0.0 & 0.0 & 0.0 & 0.0 & 0.0 & 0.0 & 0.0 & NS \\
\hline Food crops & $0.8 \pm 0.4$ & $0.7 \pm 0.3$ & $0.8 \pm 0.5$ & $0.7 \pm 0.3$ & $0.8 \pm 0.7$ & $0.8 \pm 0.5$ & $0.7 \pm 0.3$ & NS \\
\hline Cash crop & $0.5 \pm 0.2$ & $0.5 \pm 0.2$ & $0.4 \pm 0.2$ & $0.3 \pm 0.2$ & $0.5 \pm 0.2$ & $0.6 \pm 0.7$ & $0.9 \pm 0.6$ & $0.017^{*}$ \\
\hline Pasture land & $0.6 \pm 0.6$ & $0.3 \pm 0.1$ & $0.8 \pm 0.6$ & $0.6 \pm 0.6$ & $0.8 \pm 0.7$ & $0.3 \pm 0.2$ & $0.8 \pm 0.6$ & $0.000 * *$ \\
\hline Wetlands & $0.4 \pm 0.3$ & $0.5 \pm 0.1$ & $0.6 \pm 0.4$ & $0.6 \pm 0.4$ & $0.6 \pm 0.4$ & $0.3 \pm 0.2$ & $0.4 \pm 0.2$ & NS \\
\hline Resident years & $26.8 \pm 2.0$ & $41.0 \pm 1.8$ & $35.6 \pm 1.4$ & $32.8 \pm 2.7$ & $43.0 \pm 1.8$ & $44.8 \pm 2.7$ & $43.0 \pm 1.8$ & NS \\
\hline Food shortage & $3.6 \pm 0.4$ & $3.6 \pm 0.4$ & $4.4 \pm 0.3$ & $4.3 \pm 0.2$ & $4.0 \pm 0.2$ & $4.4 \pm 0.3$ & $4.4 \pm 0.3$ & NS \\
\hline \multicolumn{9}{|l|}{ Household cash } \\
\hline $\begin{array}{l}\text { incomes(ETB) } \\
\text { Total }\end{array}$ & $80,075.85 \pm 13,237.75^{\mathrm{a}}$ & $69,363.80 \pm 11,234.65^{{ }^{*}}$ & $39,363.80 \pm 21,914.45^{\text {ab }}$ & $45,075.85 \pm 10,237.75^{\text {bb }}$ & $35,075.85 \pm 9,237.77^{5 x}$ & $60.075 .85 \pm 13.237 .75^{a}$ & $57,075.85 \pm 21,237.75^{\mathrm{a}}$ & $0.01^{*}$ \\
\hline Agriculture & $58,965.52 \pm 7,841.79^{\mathrm{s}}$ & $54,446.45 \pm 7,899.30^{\text {th }}$ & $26,335.45 \pm 6,899.40^{\text {th }}$ & $37,423.45 \pm 7,799.60^{\mathrm{ab}}$ & $27,845.15 \pm 7,739.21^{\text {th }}$ & $49,564.45 \pm 5,766.30^{6}$ & $48,965.52 \pm 6,540.98^{b}$ & $0.05^{*}$ \\
\hline Livestock & $40,644.82 \pm 6,599.54^{\text {sb }}$ & $37,533.82 \pm 5,543.40^{\circ}$ & $39,984.22 \pm 7,453.46^{d b}$ & $40,897.88 \pm 7,645.90^{3}$ & $32,980.31 \pm 7,555.53^{\text {ab }}$ & $46,645.22 \pm 7,790.45^{b}$ & $50,684.80 \pm 7,500.60^{\mathrm{a}}$ & $0.01^{*}$ \\
\hline Forest product & $18,666.67 \pm 15,666.67^{a}$ & $27,937.50 \pm 2,161.15^{ \pm}$ & $5,100.00 \pm 1,805.55^{\mathrm{a}}$ & $9,720.00 \pm 3,335.93^{\mathrm{a}}$ & $10,310.00 \pm 3,342.33^{\mathrm{a}}$ & $25,982.14 \pm 8,182.06^{\circ}$ & $8,745.60 \pm 8,666.15^{\circ}$ & $0.004^{*}$ \\
\hline Off farm & $67,789.35 \pm 13,121.30^{2}$ & $36,789.66 \pm 12,079.31^{a}$ & $19,722.90 \pm 11,401.36^{\mathrm{a}}$ & $28,735.04 \pm 16,021.00^{\mathrm{a}}$ & $30,789.67 \pm 16,021.36^{\mathrm{a}}$ & $33,789.65 \pm 15,021.36^{6}$ & $36,987.45519,682.48^{d}$ & $0.008^{*}$ \\
\hline
\end{tabular}

LSD is least significant difference; NS denotes no significant difference at $p \leq 5 \%$ level. Household incomes means (row) with a common superscript imply the mean difference is not significant at $p \leq 5 \%$ level. " $*$ " refers to significance level at 5\%;“***” denotes significance at $1 \%$. 


\section{Assets}

Livestock

Livestock keeping is an important economic activity undertaken by households. The average number of cattle, sheep, goats, donkeys, and hens was 4.0, 2.0, 6.0, 1.0, and 5.0, respectively, and the mean Tropical Livestock Unit (TLU) per household was 4.65 units. Total livestock units per household across locations were significantly different $((4,367)=11.86 ; p<0.05)$. Separation of means by Tukey B test showed that TLU for households in Mender-42 $($ Mean $=3.49$, standard deviation $(\mathrm{SD})=2.81$ and Afasizm $($ Mean $=6.33$, SD = 2.60) ) were significantly different. However, households in 3 locations of Shoborat (Mean $=4.99, \mathrm{SD}=1.84$ ), Jematsa (Mean $=5.02, \mathrm{SD}=1.71)$ and Basha Buda $(\mathrm{Mean}=5.10, \mathrm{SD}=2.46)$ were not significantly different in livestock units. Wealth group differed significantly in total livestock units $((2,367)=8.06 ;<0.05)$. Separation of means by Tukey $\mathrm{B}$ test showed that, livestock holding (TLU) for indigenous and non-indigenous groups were significantly different $((7,367)=10.410, p<0.05)$

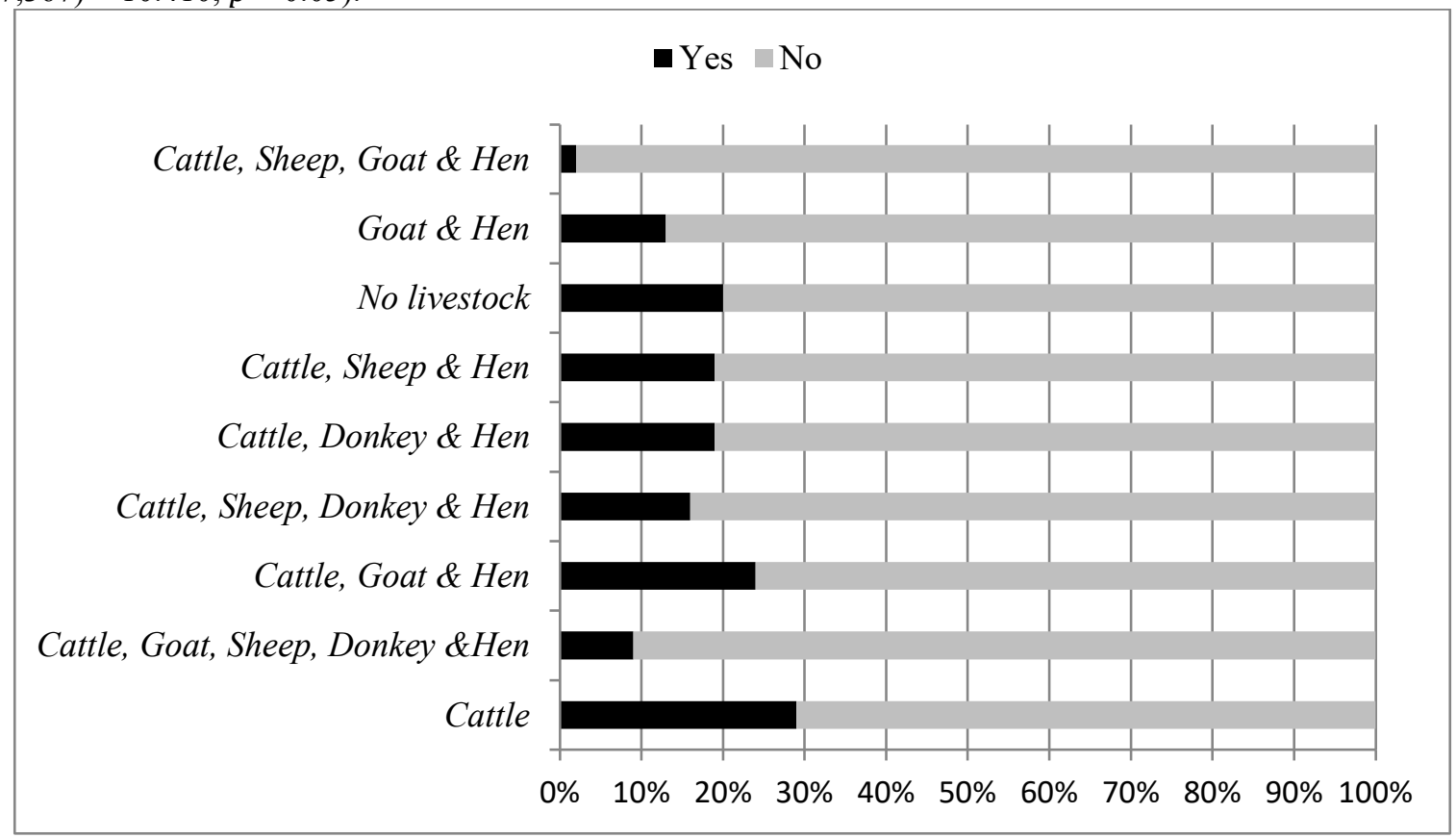

Figure 8: Live stocks reared in all locations studied

\section{Land}

Most households in the study area allocate their land use to crops (both cash and food). Between 52\% and 74\% of the land holding is allocated for agricultural crops and less than $21 \%(14.2 \%-21 \%)$ was allocated to forest resources (not planted but natural regeneration) (Table 2). Total land size, land under cash crops, and pasture were significantly different; moreover land under forests (natural), food crops, and wetlands were not significantly different (Table 2). The ownership of land differs across locations with highest number of households indicating alternative ownership of land was highest in Shobora, Jematsa, Afasizm and Basha Buda (100\%) and least in Mender-48 and Megele-39 (54.0\%). There was a strong association between alternative land ownership, Ethnicity and location $(\chi 2=118.65, \mathrm{df}=4, p<0.001)$.

\section{Forest Use and Dependence}

\section{Sources of Forest Products}

Diverse forest products were collected by households for home consumption and for sale (Table 2). Generally most of the products in all kebeles were obtained from community forests identified as biodiversity hotspot areas. For example, most households reportedly obtained their construction materials, firewood, animal fodder and fiber from community forest identified as biodiversity hotspots compared to the other sources $(90 \%, 76.9 \%, 71 \%$ and $69.3 \%$, resp.) and this was similarly observed for all products (Figure 2). About sixty percent of all households in all kebeles studied obtain forest products for agricultural tool making and about $59 \%$ of them harvest forest materials for house and house tool construction. Households obtained foods products such as indigenous fruits, vegetables roots $(69.0 \%)$, and honey (38\%) from community forests compared to other sources (own farms and markets). About fifty percent of the households obtained medicinal herbs from public forest. In the study area, $57.0 \%, 35.7 \%$, and $54.8 \%$ of households reportedly obtained construction materials (timber, poles, and fibers, resp.) from the public forest (Figure 9). 


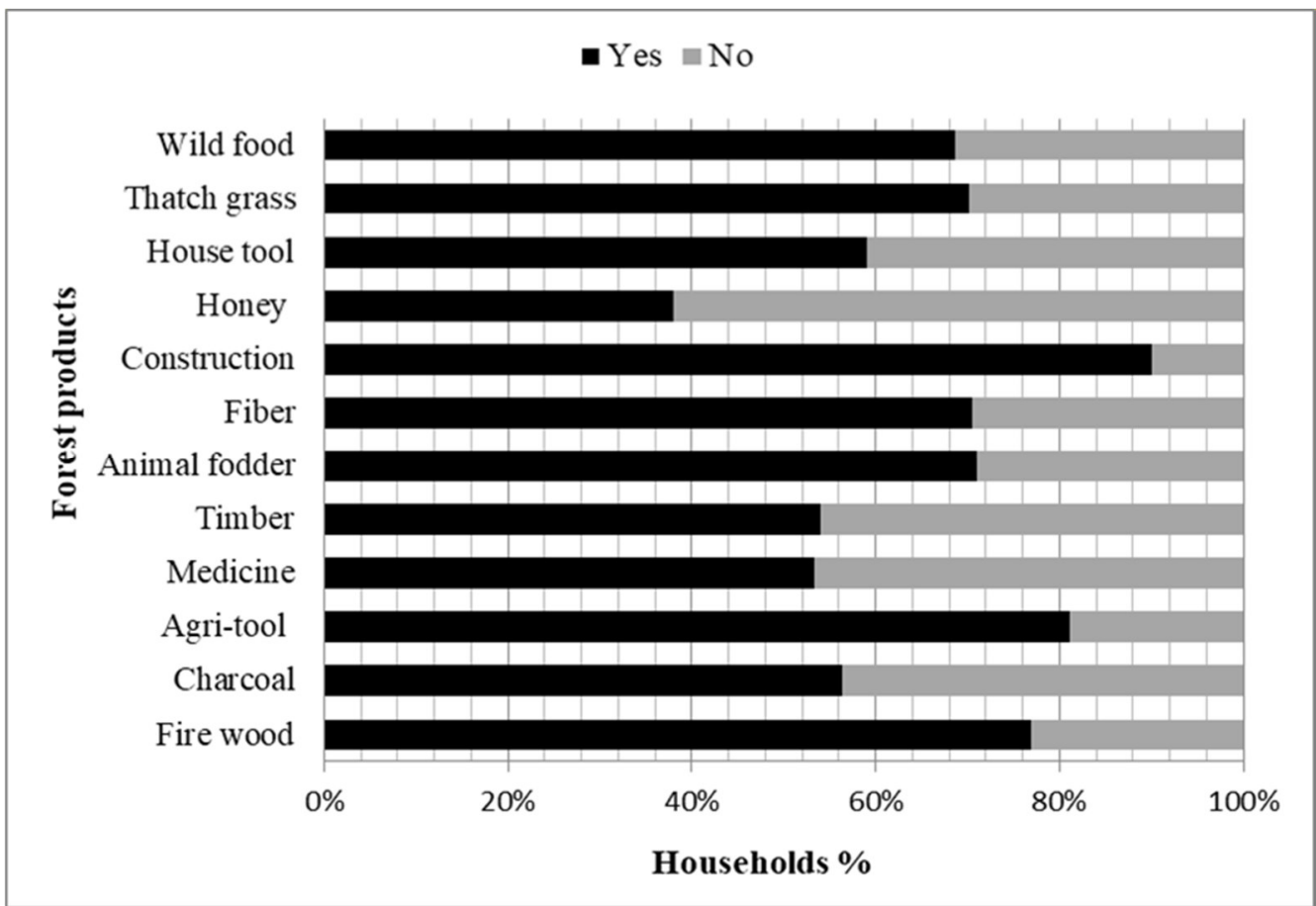

Figure 9: Reported sources of forest products by HHs in all kebeles studied (N=151)

Quantities and Value of Forest Products

The extent of use and monetary value of various products is shown in Table 3. Most households in the study area collected agricultural tool making materials $(81.1 \%)$, firewood $(76.9 \%)$, animal fodder $(71.5 \%)$, Fiber $(70.5 \%)$, and honey (27.4\%) and the least collected product was building stones (5.7\%) (Figure 10).

Figure 10: Proportion of households (\%) collecting various forest products from three biodiversity hotspot areas

Construction material is the most collected forest material/ product from all locations studied (90\%). Firewood is the second most collected product by households and each household collect an average of 122.00 backloads $(4,100.00 \mathrm{~kg}$ ) of firewood per year worth about ETB 25,447.00 (US\$ 771.00) accounting for 5.7\% of forest income (Table 4). Another popular product collected by households is charcoal (83.3\%) with an average of about 4,505 kg per year. However, in terms of monetary value per household charcoal, honey and poles score high. The values of these products are ETB 54,156.00 (US\$ 1,641.00), 69,424.00 (US\$ 2103.00), and 32,959.00 (US\$ 999.00), respectively (Table 4).

Table 3: Quantities and monetary value of forest products collected by households per year

\begin{tabular}{lllll}
\hline Products & Unit & Quantity & \multicolumn{2}{c}{ Value } \\
\cline { 4 - 5 } & & & $(\mathrm{EBR})$ & US\$ \\
\hline Firewood & $\mathrm{kg}$ & $4,070.45 \pm 167.67$ & $25,447.47 \pm 1104.60$ & $282.75 \pm 12.27$ \\
Medicine & $\mathrm{kg}$ & $48.78 \pm 2.69$ & $7,677.09 \pm 1781.22$ & $150.30 \pm 19.79$ \\
Poles & $\mathrm{Number}$ & $343.22 \pm 17.62$ & $32,959.22 \pm 1855.49$ & $366.21 \pm 20.62$ \\
Honey & $\mathrm{kg}$ & $102.39 \pm 16.95$ & $69,424.33 \pm 5301.33$ & $2103.38 \pm 58.90$ \\
Agricultural tools & Number & $104.73 \pm 17.50$ & $1,053.82 \pm 174.60$ & $21.71 \pm 1.94$ \\
House tools & Number & $1251.73 \pm 117.50$ & $11,053.82 \pm 274.60$ & $56.78 \pm 21.94$ \\
Wild food & Kg & $256.68 \pm 23.44$ & $9,573.34 \pm 552.13$ & $106.37 \pm 6.13$ \\
Timber & $\mathrm{Running}$ feet & $171.38 \pm 18.46$ & $18,292.06 \pm 1963.06$ & $203.25 \pm 21.81$ \\
Fiber & $\mathrm{kg}$ & $251.77 \pm 38.98$ & $4,227.20 \pm 383.12$ & $46.97 \pm 4.26$ \\
Charcoal & $\mathrm{kg}$ & $4,505.55 \pm 1103.20$ & $54,156.77 \pm 2375.53$ & $1,601.74 \pm 248.62$ \\
Thatch grass & $\mathrm{kg}$ & $179.08 \pm 27.80$ & $14,530.72 \pm 7,142.99$ & $435.34 \pm 79.37$ \\
\hline
\end{tabular}

Values are arranged as means, followed by standard error of means.

Household who graze their livestock in community forest ranged from 57.1\% (Shobora) and the highest of $77.9 \%$ of households in Jematsa. Overall, $66.8 \%$ of the households reported using the forest as a source of fodder for their livestock. The monetary value of this use ranged from ETB 11,983.00 (US\$ 363.00) to 17,974.00 (US\$ 545.00) per household per year. Wood fuel (firewood and charcoal) is the dominant source of forest income with a mean of $49.1 \%$ of forest income per household and this was followed by structural and fiber products $(26.5 \%)$ and grass products $(17.4 \%)$. Though charcoal is not the most Collected products $(9.9 \%)$ of households 
yet its contribution was significant contributing $43.4 \%$ to household forest income due its high value. Other products which made significant contribution to household forest income were poles and honey each contributing $13.0 \%$ and $12.4 \%$, respectively. The total forest income ranged from $28.8 \%$ to $36.5 \%$ with overall mean of $32.5 \%$ (Table 5).

Table 4: Contribution of forest products category to forest income

\begin{tabular}{|c|c|c|c|c|c|c|c|c|}
\hline Products & $\begin{array}{l}\text { Mender } \\
-42\end{array}$ & $\begin{array}{l}\text { Mender } \\
-48\end{array}$ & $\begin{array}{l}\text { Jemats } \\
\text { a }\end{array}$ & $\begin{array}{l}\text { Shobor } \\
\text { a }\end{array}$ & $\begin{array}{l}\text { Afasiz } \\
\text { m }\end{array}$ & $\begin{array}{l}\text { Megele- } \\
39\end{array}$ & $\begin{array}{l}\text { Bashabu } \\
\text { da }\end{array}$ & Mean \\
\hline Fuel & 17.20 & 17.20 & 59.80 & 50.30 & 51.40 & 66.90 & 49.10 & 44.56 \\
\hline - Firewood & 10.80 & 3.60 & 45.90 & 24.40 & 34.40 & 15.80 & 33.80 & 19.38 \\
\hline - Charcoal & 6.40 & 13.60 & 13.90 & 25.60 & 17.00 & 51.10 & 15.30 & 20.70 \\
\hline Food & 26.60 & 28.30 & 28.70 & 29.00 & 19.70 & 19.70 & 26.50 & 24.50 \\
\hline - $\quad$ Fruits & 1.00 & 3.10 & 3.10 & 2.80 & 1.90 & 1.90 & 2.10 & 2.10 \\
\hline - Honey & 9.40 & 15.50 & 13.40 & 13.90 & 13.90 & 10.00 & 12.40 & 12.40 \\
\hline - Tubers & 14.10 & 14.10 & 7.60 & 14.10 & 10.00 & 8.40 & 9.10 & 9.10 \\
\hline - Meat & 2.00 & 2.00 & 2.60 & 4.80 & 4.80 & 2.30 & 2.70 & 2.70 \\
\hline $\begin{array}{l}\text { Structural and } \\
\text { fiber }\end{array}$ & 46.00 & 7.10 & 14.40 & 11.80 & 14.40 & 11.80 & 17.40 & 26.50 \\
\hline - Timber & 6.40 & 2.70 & 5.40 & 4.00 & 6.40 & 4.00 & 4.10 & 4.10 \\
\hline - $\quad$ Poles & 39.40 & 4.30 & 4.30 & 8.50 & 8.50 & 7.60 & 7.60 & 13.00 \\
\hline $\begin{array}{l}\text { - Agricultura } \\
1 \text { tools }\end{array}$ & 60.20 & 30.10 & 51.10 & 80.60 & 64.30 & 36.30 & 53.34 & 0.30 \\
\hline Grass & 7.60 & 3.80 & 4.60 & 5.10 & 4.60 & 5.10 & 5.10 & 17.50 \\
\hline $\begin{array}{l}\text { - Thatch } \\
\text { grass }\end{array}$ & 1.10 & 1.10 & 0.80 & 2.00 & 2.80 & 1.60 & 1.60 & 1.60 \\
\hline - Fodder & 6.50 & 2.70 & 2.70 & 3.70 & 3.10 & 1.80 & 3.60 & 3.60 \\
\hline Medicine & 2.60 & 0.90 & 2.00 & 2.60 & 2.60 & 0.90 & 2.00 & 5.10 \\
\hline Others & 0.00 & 0.10 & 0.00 & 0.00 & 0.00 & 0.20 & 0.20 & 0.10 \\
\hline Total & 100.00 & 100.00 & 100.00 & 100.00 & 100.00 & 100.00 & 100.00 & 100.00 \\
\hline $\begin{array}{l}\% \text { of total } \\
\text { household income }\end{array}$ & 28.80 & 30.70 & 32.90 & 36.50 & 36.50 & 33.40 & 32.50 & 32.50 \\
\hline $\begin{array}{l}\text { Absolute value } \\
\text { (ETB) }\end{array}$ & $\begin{array}{l}47,662 . \\
00\end{array}$ & $\begin{array}{l}63,427 . \\
00\end{array}$ & $\begin{array}{l}65,218 \\
00\end{array}$ & $\begin{array}{l}65,200 \\
00\end{array}$ & $\begin{array}{l}66,580 \\
00\end{array}$ & $\begin{array}{l}71,642 . \\
00\end{array}$ & $62,906.00$ & $\begin{array}{l}62,906 . \\
00\end{array}$ \\
\hline $\begin{array}{l}\text { Absolute value } \\
\text { (US\$) }\end{array}$ & 1444.00 & 1922.00 & 1976.00 & 1975.00 & 2017.00 & 2170.00 & 1906.00 & 1906.00 \\
\hline
\end{tabular}

\section{Forest Dependence}

The households in Bambasi and Assosa are dependent on forest for various products and services. The net forest income and relative forest income are summarized in Table 6 . The forest dependence was calculated as the ratio of total forest income to the total household income and expressed as a percentage. The level of dependence was greater than $25 \%$ in all study locations, ranging from $28.8 \%$ to $36.5 \%$ with overall mean of $33.7 \%$ (Table 6 ). The absolute forest income and relative forest income were not significantly different between households in the seven study locations. Absolute forest income and relative forest income (\%) were not significantly different across study locations $((4,309)=1.76 ; p>0.05)$ (Table 5$)$.

Table 5: Absolute forest income and relative forest income (\%) by study Kebele

\begin{tabular}{ccc}
$\begin{array}{c}\text { Variable } \\
\text { (Kebeles) }\end{array}$ & Absolute forest income (ETB) & Relative forest income (\%) \\
\hline Mender-42 & $47,662.10 \pm 6,236.81 \mathrm{a}$ & $28.85 \pm 3.70 \mathrm{a}$ \\
Mender-48 & $63,427.11 \pm 6,470.64_{\mathrm{b}}$ & $30.71 \pm 3.34 \mathrm{a}$ \\
Jematsa & $65,217.56 \pm 4,801.03_{\mathrm{b}}$ & $32.89 \pm 2.18 \mathrm{a}$ \\
Shobora & $66,579.73 \pm 3,762.37_{\mathrm{b}}$ & $36.46 \pm 1.84 \mathrm{a}$ \\
Afasizm & $71,641.51 \pm 4,711.57_{\mathrm{b}}$ & $33.42 \pm 2.40 \mathrm{a}$ \\
Megele-39 & $71,641.51 \pm 4,711.57_{\mathrm{b}}$ & $33.42 \pm 2.40 \mathrm{a}$ \\
Basha Buda & $66,789.73 \pm 4,762.37 \mathrm{~b}$ & $36.46 \pm 1.84 \mathrm{a}$ \\
Overall mean & $65,836.28 \pm 2,232.06$ & $33.73 \pm 1.10$ \\
& $F_{(4309)}=1.76, P<0.05$ & $F(4294)=1.18, P<0.05$ \\
\hline
\end{tabular}

Note. Means (column) with a common (letters) superscript imply the mean difference is not significant different at $p \leq 5 \%$ level. 
Floristic Composition, Diversity and Structure of Biodiversity hotspot areas

Floristic composition

A total of 118 plant species were identified which belongs to 97 genera from 46 families (Table 11 and Annex 14). Out of the 118 identified plant species, 39 species $(33.05 \%)$ were trees, 14 species $(11.86 \%)$ were shrubs, 14 species $(11.86 \%)$ were climbers and the rest 51 species $(43.22 \%)$ were herbs. However, the proportion of the habits differs from forest to forests (Table 7)

Table 6: Number, percentage and life forms of plant species identified from Biodiversity hotspot areas.

\begin{tabular}{llll}
\hline Hotspot areas & Life form & Number & Percentage \\
\hline \multirow{4}{*}{ Anbessa Forest } & Trees & 39 & 33.05 \\
& Shrubs & 14 & 11.86 \\
& Climbers & 14 & 11.86 \\
& Herbs & 51 & 43.22 \\
Kolkis Forest & & \\
& Trees & 36 & 30.51 \\
& Shrubs & 14 & 11.86 \\
& Climbers & 13 & 11.02 \\
& Herbs & 55 & 46.61 \\
Mender-42 Forest & & & \\
& Trees & 43 & 36.44 \\
& Shrubs & 40 & 33.90 \\
& Climbers & 25 & 21.19 \\
\hline
\end{tabular}

Diversity and Richness of Plants in Three Biodiversity Hotspot Sits

The results showed that the diversity in the kolkis has the highest value (1.267) and the lowest was in mender-42 forest $(0.352)$ (Table 8$)$. In the case of equitability or evenness, there was a significant difference $(p<0.05)$ between the sits in which kolkis again had the highest $(0.850)$ while Anbesa forest reserve had the lowest $(0.388)$. The species richness was also different in both sits whereby the mender-42 forest had the highest value (8.36) than the kolkis forest reserves (6.47).

Table 7: Diversity, evenness and species richness of plants in different biodiversity hotspot sites of Assosa and Bambasi District

\begin{tabular}{llll}
\hline & \multicolumn{3}{c}{ Biodiversity Hotspot Sites Selected } \\
\cline { 2 - 4 } & Kolkis Forest & Anbessa forest & Mender-42 forest \\
\hline Shannon's diversity index $(\mathrm{H})$ & $1.267^{\mathrm{a}}$ & $0.628^{\mathrm{a}}$ & $0.352^{\mathrm{b}}$ \\
Equitability (evenness) $\left(\mathrm{E}_{\mathrm{H}}\right)$ & $0.850^{\mathrm{c}}$ & $0.388^{\mathrm{a}}$ & $0.660 \mathrm{a}^{\mathrm{b}}$ \\
Species richness & $6.47^{\mathrm{b}}$ & $2.86^{\mathrm{a}}$ & $8.36^{\mathrm{b}}$ \\
\hline
\end{tabular}

Note: Values with the same letters in the same rows are not significantly different $(p<0.05)$

Endemic plant species

From all biodiversity hot spot areas nine endemic plant species of Ethiopia which belongs to seven Families were recorded (Table 9). 
Table 8: List of Endemic plant species of Ethiopia recorded from the three biodiversity hotspots

\begin{tabular}{|c|c|c|c|}
\hline Biodiversity Hotspot areas & Scientific Name & Family & Habit \\
\hline \multirow{9}{*}{ Abessa Forest } & Albizia malacophylla (A. Rich.) & Fabaceae & Tree \\
\hline & Berkheya chiesiana Chiov. & Asteraceae & Herb \\
\hline & Crinipes abyssinicus (Hochst. ex A. Rich.) & Poaceae & Herb /Grass \\
\hline & Dombeya aethiopica Gilli. & Sterculiaceae & Tree \\
\hline & Lippia adoënsis Hochst. ex Walp. & Verbenaceae & Shrub \\
\hline & Mucuna melanocarpa Hochst. ex A. Rich & Fabaceae & Climber \\
\hline & Pimpinella heywoodii Abebe & Apiaceae & Herb \\
\hline & Tragia abortiva M. Gilbert & Euphorbiaceae & Shrub \\
\hline & Tragia doryodes M. Gilbert & Euphorbiaceae & Climber \\
\hline \multirow{8}{*}{ Kolkis Forest } & Albizia malacophylla (A. Rich.) & Fabaceae & Tree \\
\hline & Berkheya chiesiana Chiov. & Asteraceae & Herb \\
\hline & Crinipes abyssinicus (Hochst. ex A. Rich.) & Poaceae & Herb /Grass \\
\hline & Dombeya aethiopica Gilli. & Sterculiaceae & Tree \\
\hline & Lippia adoënsis Hochst. ex Walp. & Verbenaceae & Shrub \\
\hline & Mucuna melanocarpa Hochst. ex A. Rich & Fabaceae & Climber \\
\hline & Pimpinella heywoodii Abebe & Apiaceae & Herb \\
\hline & Tragia doryodes M. Gilbert & Euphorbiaceae & Climber \\
\hline \multirow{7}{*}{ Mender-42 Forest } & Albizia malacophylla (A. Rich.) & Fabaceae & Tree \\
\hline & Berkheya chiesiana Chiov. & Asteraceae & Herb \\
\hline & Dombeya aethiopica Gilli. & Sterculiaceae & Tree \\
\hline & Lippia adoënsis Hochst. ex Walp. & Verbenaceae & Shrub \\
\hline & Mucuna melanocarpa Hochst. ex A. Rich & Fabaceae & Climber \\
\hline & Tragia abortiva M. Gilbert & Euphorbiaceae & Shrub \\
\hline & Tragia doryodes M. Gilbert & Euphorbiaceae & Climber \\
\hline
\end{tabular}

Plant community classification by Biodiversity Hotspot areas

Anbessa and Kolkis Forests

The vegetation data matrix of both Anbessa and Kolkis forests were analyzed and classified in to one because of similarities in their pattern of variation in species composition. The data set consisting 30 woody plant species in 30 relevés were used in plant community classification. The woody vegetation of Anbessa forest was classified into four clusters (Figure 6).

I. Pittosporum viridiflorum - Syzygium guineense subsp. Afromontanum Community

This community includes trees such as: Pittosporum viridiflorum, Syzygium guineense subsp. afromontanum, Albizia gummifera and Gardenia ternifolia. The ground layer is dominated by Aframomum alboviolaceum.

II. Oxytenanthera abyssinica - Combretum molle - Syzygium guineense subsp.

\section{macrocarpum Community}

This plant community occurs within a larger part of Anbessa forest. It was recorded between 1413 to 1563 m.a.s.l. This community includes trees and shrubs such as: Oxytenanthera abyssinica, Combretum molle, Syzygium guineense subsp. macrocarpum, Annona senegalensis, Lannea welwitschii, Dombeya quinqueseta and others.Piliostigma thonningii and Terminalia macroptera

III. Piliostigma thonningii - Terminalia macroptera community

This plant community occurs relatively to the lower part of Anbessa forest. It was recorded around 1338 m.a.s.l. This community includes trees such as: Piliostigma thonningii, Lonchocarpus laxiflorus, Terminalia macroptera, Terminalia laxiflora, Entada africana, Albizia malacophylla, Combretum collinum and others.

IV. Combretum collinum - Dombeya quinqueseta - Securidaca longepedunculata Community

This plant community occurs in intermediate elevation. It was recorded at an altitude of 1442 m.a.s.l. This community includes trees such as: Combretum collinum, Dombeya quinqueseta,

Entada africana, Maytenus undata, Pterocarpus lucens, Securidaca longepedunculata, Steganotaenia araliacea, Stereospermum kunthianum,Terminalia laxiflora and Vitex doniana 


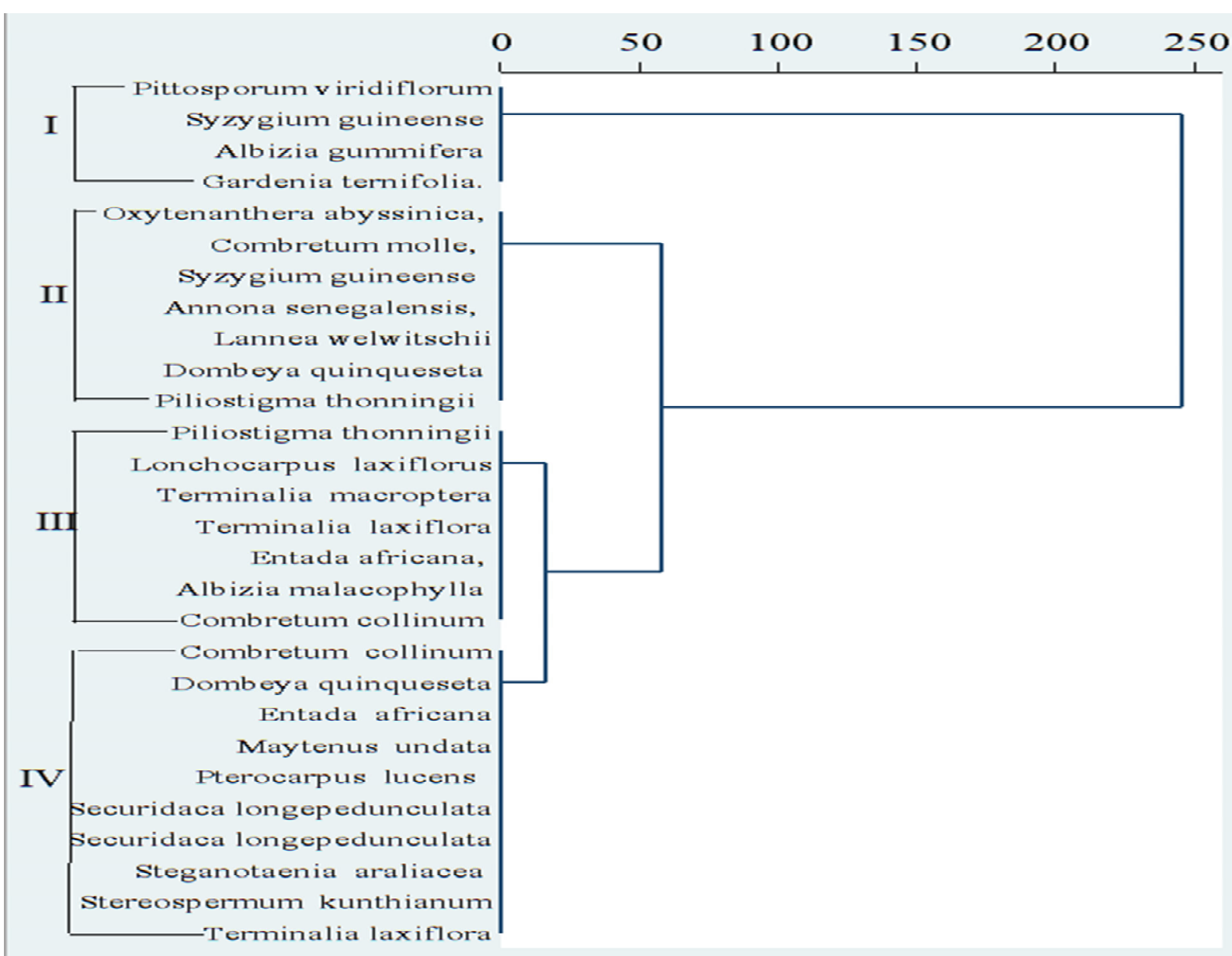

Figure 11: Dendrogram showing the classification of plant species based on the plant communities (Anbessa and Kolkis Forests). The horizontal axis represents the distance or dissimilarity between clusters and the vertical axis represents the species and clusters.

\section{Community description Mender-42 Forest}

Based on the dominant species, four main community types were identified and categorized as follows:-

\section{Combretum molle-Croton macrostachyus (community I)}

This is the community dominated by: Accacia negrescens, Acacia sp, Ximenia Americana, Albizia malacophylla, Loncocapus laxiflorus, Berchemia discolor, Pterocarpus lucens and others. This community type is made up of 54 plant species which is $84 \%$ of all the species identified in the study area. This community is also wide spread in all the sites at almost the same.

\section{Dichrostachys cinerea-Carrisa spinarum (community II)}

Dichrostachys cinerea and Carrisa spinarum were the dominant species in community II. It consisted of 12 plant species, which accounted for $18.8 \%$ of the total species. Five species in the community are wild food plants. This type of community was completely restricted in to some areas in the area.

\section{Cordia africana-Terminalia laxiflora community (Community III)}

This community is dominated by the Cordia Africana and Terminalia laxiflora. Community III is made up of 23 plant species. The community also is widespread in the other forest reserve.

IV. Ziziphus abyssinica-Syzygium guineense community (Community IV)

This community is dominated by: Flugea virisa, Mythenus senegalensis, Securidaca longepedanculata, Strychnos spinosa, Mimisops kummel, Vitex doniana, Combretum molle, Ziziphus abyssinica and other species . Community IV is made up of 41 plant species. 


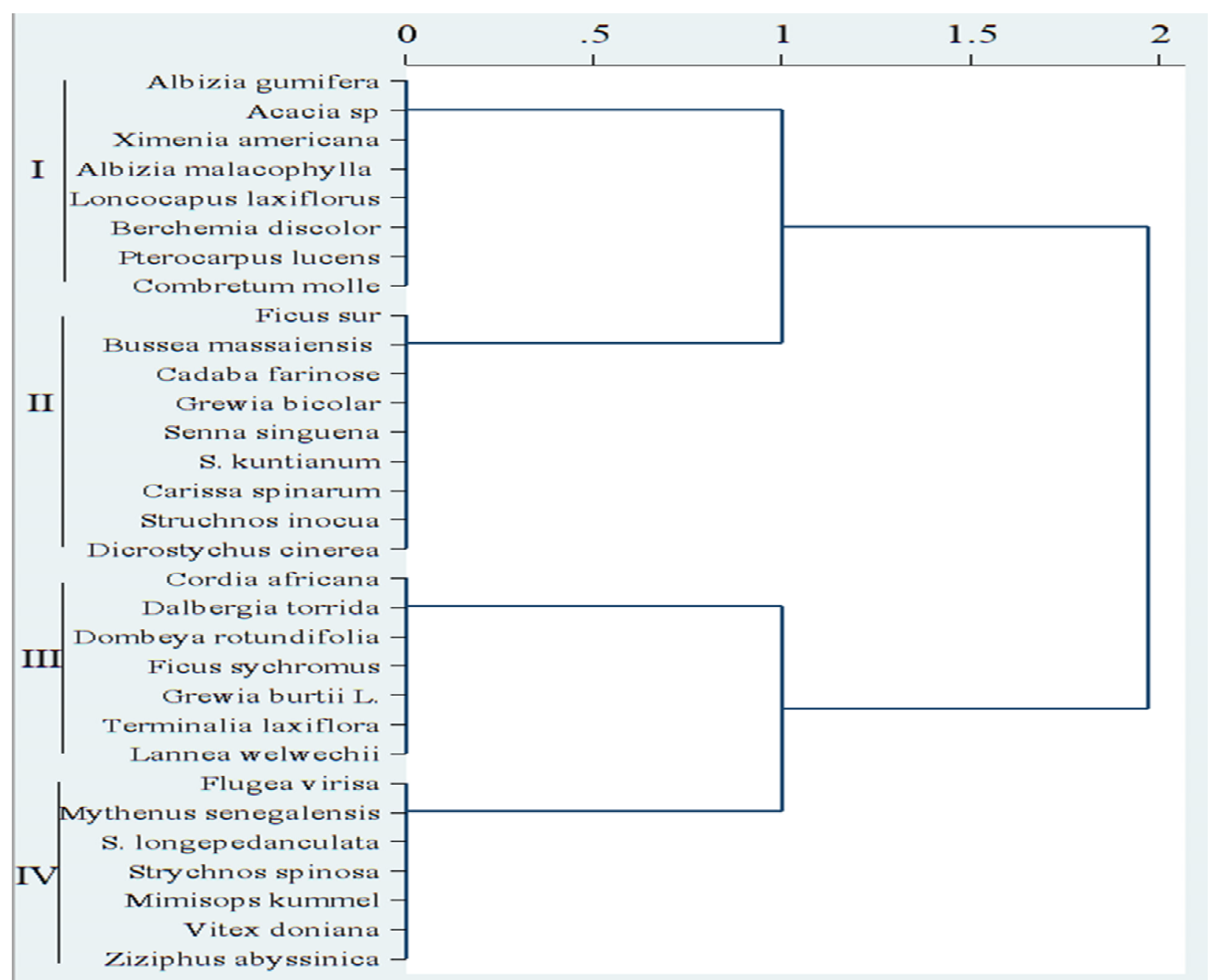

Figure 12: Dendrogram showing the classification of plant species based on the plant communities (Mender 42 Forest). The horizontal axis represents the distance or dissimilarity between clusters and the vertical axis represents the species and clusters.

\section{The Faunal diversity of biodiversity hotspots}

The three hotspot area selected such as Anbessa, Kolkis and Mender-42 are rich in Fauna species. The areas are home to 20 species of mammals, over 60 species of birds, 12 species of fish, and small mammals, bats, reptiles, and amphibians. The Mammalian species include: Warthog, Aardvark, Grimm's Duiker, Oribi, Tiang, Defassa Waterbuck, Abyssinian Bohor Reedbuck, Red-fronted Gazelle, Roan Antelope, Abyssinian Bushbuck, Greater Kudu, Lion, leopard, Spotted, Hyena, Striped Hyena, Civet, Ratel, Serval, Common Jackal, Common Genet, Wild Cat, Anubis baboon, Patas Monkey and Vervet Monkey. The bird species includes Arabian Bustard, White-bellied Bustard, Tufted Guinea-fowl, Clapperton's Francolin, Colourful starlings (Spreo spp), Bee-eaters (Merops spp), Sunbirds (Nectarinia spp), Herons (Ardea spp), Egrets (Casmerodius spp), Rollers (Coracias spp) (Table 10). The biodiversity hotspot areas are also famous of many other different species including Eurasian migrants. This is because the region is found in a major flyway that used by birds migrating between Eurasia and Africa. Nile Crocodile, Nile Monitor Lizard, Savannah Monitor Lizard, Python, and other venomous and non-venomous snakes are abundantly found reptiles of the areas studied. The streams which are found in the forests maintain the age and annual flow of riveres below the forests which then enable the living of the fishs and occasionally persist until the next wet season. Important fish species include Clarias laser, Heterodox niloticus, Synodontus spp, Bagrus bayad, Lates niloticus and Tilapia niloticus. 
Table 9: Some of animals and birds identified in Anbessa, Kolkis and Mender-42 Forest

\begin{tabular}{|c|c|c|}
\hline Common Name & Method Of Identification & Biodivesity Hotspot area \\
\hline Crested porcupine & Spine & $\mathrm{AnF}, \mathrm{KlF}, \mathrm{M}-42 \mathrm{~F}$ \\
\hline Rock hyrax & Visual/faeces & $\mathrm{AnF}, \mathrm{K} 1 \mathrm{~F}$ \\
\hline Bush hyrax & Visual/faeces & $\mathrm{AnF}, \mathrm{KlF}$ \\
\hline Stark's hare & Faeces & AnF, K1F, M-42F \\
\hline Patas Monkey & Visual & $\mathrm{AnF}, \mathrm{KlF}, \mathrm{M}-42 \mathrm{~F}$ \\
\hline Vervet Monkey & Visual & $\mathrm{AnF}, \mathrm{KlF}, \mathrm{M}-42 \mathrm{~F}$ \\
\hline Guereza & Visual & $\mathrm{AnF}$ \\
\hline Common bush & Visual & AnF, K1F, M-42F \\
\hline Common diker & Visual & $\mathrm{AnF}, \mathrm{KlF}, \mathrm{M}-42 \mathrm{~F}$ \\
\hline Klipspringer & Visual & $\mathrm{AnF}, \mathrm{K} 1 \mathrm{~F}$ \\
\hline Leopard & Word of mouth & $\mathrm{AnF}, \mathrm{KlF}$ \\
\hline Serval cat & Word of mouth & $\mathrm{AnF}, \mathrm{KlF}, \mathrm{M}-42 \mathrm{~F}$ \\
\hline Caracal & Word of mouth & $\mathrm{AnF}, \mathrm{KlF}$ \\
\hline Spotted hyaena & Word of mouth & $\mathrm{AnF}, \mathrm{KlF}, \mathrm{M}-42 \mathrm{~F}$ \\
\hline Common Jackal & Visual & $\mathrm{AnF}, \mathrm{KlF}, \mathrm{M}-42 \mathrm{~F}$ \\
\hline Black-backed Jackal & Word of mouth & $\mathrm{AnF}, \mathrm{K} 1 \mathrm{~F}$ \\
\hline White tailed Mongoose & Word of mouth & $\mathrm{KlF}$ \\
\hline Honey Badger & Feaces & $\mathrm{AnF}, \mathrm{KlF}, \mathrm{M}-42 \mathrm{~F}$ \\
\hline Common mole rat & Digging & $\mathrm{AnF}, \mathrm{KlF}, \mathrm{M}-42 \mathrm{~F}$ \\
\hline Warthog & Visual & $\mathrm{AnF}, \mathrm{KlF}, \mathrm{M}-42 \mathrm{~F}$ \\
\hline Buffalo & Word of mouth & $\mathrm{KIF}$ \\
\hline Arabian Bustard & Visual & $\mathrm{AnF}, \mathrm{KlF}, \mathrm{M}-42 \mathrm{~F}$ \\
\hline White-bellied Bustard & Visual & $\mathrm{AnF}, \mathrm{KlF}, \mathrm{M}-42 \mathrm{~F}$ \\
\hline Tufted Guinea-fowl & Visual & $\mathrm{AnF}, \mathrm{KlF}, \mathrm{M}-42 \mathrm{~F}$ \\
\hline Clapperton's Francolin & Visual & $\mathrm{AnF}, \mathrm{KlF}, \mathrm{M}-42 \mathrm{~F}$ \\
\hline Colourful starlings & Visual & $\mathrm{AnF}, \mathrm{KlF}, \mathrm{M}-42 \mathrm{~F}$ \\
\hline Bee-eaters & Visual & $\mathrm{AnF}, \mathrm{KlF}, \mathrm{M}-42 \mathrm{~F}$ \\
\hline Sunbirds Egrets & Visual & $\mathrm{AnF}, \mathrm{KlF}, \mathrm{M}-42 \mathrm{~F}$ \\
\hline Herons & Visual & $\mathrm{AnF}, \mathrm{KlF}, \mathrm{M}-42 \mathrm{~F}$ \\
\hline Rollers & Visual & $\mathrm{AnF}, \mathrm{KlF}, \mathrm{M}-42 \mathrm{~F}$ \\
\hline Aardvark & Word of mouth & $\mathrm{AnF}, \mathrm{KlF}$ \\
\hline Speckled Pigeon & Visual & AnF, KlF, M-42F \\
\hline Red Eyed Dove & Visual & AnF, K1F, M-42F \\
\hline Hooded Vulture & Visual & $\mathrm{AnF}, \mathrm{KlF}, \mathrm{M}-42 \mathrm{~F}$ \\
\hline Eurasian Hoopoe & Visual & $\mathrm{AnF}, \mathrm{KlF}$ \\
\hline Red Billed Horn Bill & Visual & AnF, KlF, M-42F \\
\hline Hadad Ibis & Visual & AnF, K1F, M-42F \\
\hline Abyssinian Ground Horn Bill & Visual & $\mathrm{AnF}, \mathrm{KlF}$ \\
\hline
\end{tabular}

Note: AnF $=$ Anbesa Forest, $K l F=$ Kolkis Forest, $M-42 F=$ Mender-42 Forest

\section{Conclusion and Recommendations}

The study has revealed the important role of forest resources in household income. It was found out that forest income share are higher for none settler households. However, in absolute terms, the better off households are advantaged. All the studied households showed high dependence on the forest resources despite most collection/usage being illegal. On average $33 \%$ of annual household income is generated by consumption and sale of forest products. With the increasing population in and surrounding biodiversity hotspot areas (Kolkis, Mender42 and Anbessa), the demand on forest resources are likely to rise and this will exert pressure on the state of forest resources in Assosa and Bambasi Districts. However, reflecting on the findings of this study, it would be imprudent to exclude local community from accessing forest resources because; it may lead to increased poverty and conflict. One way of managing the situation would be to allow low level extractive activities such as collection of fire wood, medicine, food, house tools and enforcing licensing procedures to allow for low extraction level, essentially for subsistence use and discourage commercial extraction through community bylaws. Another way to ease the pressure on these biodiversity hotspot areas is to promote intensification of tree growing on farms through support for agroforestry or farm forestry intervention.

Another strategy is to lower the opportunity cost of engaging in forest resources by creating robust income opportunities independent of forest product extraction or improving the technical efficiency of agricultural and production systems in order to minimize illegal forest exploitation. These measures may improve rural livelihoods 
and conserve forest resources and biodiversity.

\section{Conflicts of interest}

The authors declare there are no conflicts of interest.

\section{Acknowledgement}

First and foremost we would like to thank the Glorious God for making our effort fruitful and for the effective accomplishment of the study. Our special appreciation goes to MELKA-Ethiopia for the provision fund to do this study and all stockholder institutions such as: Benshangul Gumuz Regional and Woreda level administratives, Regional Agricultural and Rural Development bureau, Regional Environment, Land Administration and Investment Bureau, Assosa Biodiversity Center, Assosa and Bambasi Woreda administrative office, Agricultural offices of the two Woredas; Environment Land Administration and Investment offices of the two Woredas for their expertise contribution to the study. The research team sincerely thanks the farmers of the study area and all expertise of the above bureaus and offices for their kindness and enthusiasm to talk to us about the issue of the study. Indeed, it was a great experience to work with them.

\section{References}

1. Adams W, Hulme D (2001) Conservation and community. African Wildlife and Livelihoods 14: 12-17.

2. Guthiga PM (2008) Understanding local communities' perceptions of existing forest management regimes of a Kenyan rainforest. International Journal of Social Forestry 1: 145-166.

3. Emerton L (2000) Using economic incentives for biodiversity conservation, economics and biodiversity programme. World Conservation Union, Switzerland. p: 299.

4. McNeely JA (1980) Parks for life: Report of the $4^{\text {th }}$ World Congress on National Parks and Protected Areas. International Union for Conservation of Nature, Gland, Switzerland. p: 55

6. IUCN (2000) Using economic incentives for biodiversity conservation. Economics and Biodiversity Programme, New York, USA. pp: 198.

7. UNEP (2004) Integrating economic development into environmental laws. Report on legal and institutional issues in the development and harmonization of laws relating to environment. New York, USA. pp: 125.

27. UNEP (2008) Harmonization and development of environmental laws. Report on Legal and Institutional Issues in the Development and Harmonization of Laws Relating to Wildlife Management. UNEP Publications, New York, USA. pp: 170

5. Panayotou T (1994) Economic instruments for environmental management and sustainable development. Environment and Economics 6: 21-25

6. Friis, I. and Vollesen, K. (2007). Zanthoxylum gilletii (Rutaceae) - a disjunct GuineoCongolian forest tree with a newly discovered disjunction to western Ethiopia. Poster presented on $18^{\text {th }}$ AETFAT Congress in Yaoundé, Cameroon 26 February to 2 March 2007.

7. Chance, R.U. (2006). Plant communities of a wetland in western Ethiopia. M.Sc. Thesis, University of Oslo, Oslo.

CSA, (2007). CSA (2007) Ethiopia demographic and health survey 2005. Central Statistical Agency, Addis Ababa, Ethiopia.

8. Tesfaye Awas (2007). Plant Diversity in Western Ethiopia: Ecology, Ethnobotany and Conservation. PhD. Desertation. University of Oslo, Norway.

9. IFAD. 2010. Climate Change Strategy.

10. IFAD. 2011. Environment and Natural Resource Management Policy: Resilient Livelihoods Through the Sustainable Use of Natural Assets.

11. IFAD. 2016b. (Independent Office of Evaluation). Environment and Natural Resource Management Evaluation Synthesis.

12. ibid, Article 4(1) ( i) and Article 6

13. ibid, Article 2(1)

14. Alden Wily, L. 2012. Customary Land Tenure in the Modern World Rights to Resources in Crisis: Reviewing the Fate of Customary Tenure in Africa. Rights and Resources Institute. Washington, DC, USA.

15. Roe D., Nelson, F. and Sandbrook, C. (Eds) 2009. Community management of natural resources in Africa: Impacts, experiences and future directions, Natural Resource Issues No. 18, International Institute for Environment and Development. London, UK.

16. Shepherd, G. 1992. Managing Africa's dryland forests. Overseas Development Institute. London, UK.

17. Eckholm, E., Foley, G. and Timberlake, G.B. 1984. Fuelwood: The energy crisis that won't go away. Earthscan Publications, London, UK.

18. Vitousek, P.M., H. A Mooney, J. Jane Lubchenco and J.M. Melillo (1997): Human Domination of Earth's Ecosystems. Science 277: 494-499. 
19. UNCTAD (2011), World Investment Report 2011: Non-Equity Modes of International Production and Development. Geneva.

20. Dunn, R. R., N. C. Harris, R. K. Colwell, L.P. Koh and N. S. Sodhi (2009): The sixth mass coextinction: are most endangered species parasites and mutualists? Proc. R. Soc. B., 276: 3037-3045

21. IUCN (2001): IUCN Red List Categories and Criteria version 3.1. IUCN Species Survival Commission. IUCN, Gland, Switzerland.

22. FAO (2005), Responsible agricultural investments in developing countries: How to make principles and guidelines effective, Ministry for Rural Affairs Swedish FAO Committee, Elanders Sverige AB printing press.

23. Brook B.W., N.S. Sodhi and C.J.A. Bradshaw (2008): Synergies among extinction drivers under global change. Trends Ecol. Evol., 23:453-460.

24. Thomas C. D., A. Cameron, R.E. Green, M. Bakkenes, L.J. Beaumont, Y.C. Collingham et al., (2004): Extinction risk from climate change. Nature 427:145-148.

25. Rands, M.R.W., A. Clements, J.P.W. Scharlemann, W.M. Adams, D. Coomes, L. Bennun, A. Entwistle, W.J. Sutherland, S.H.M. Butchart, I. Hodge and B. Vira (2010): Biodiversity Conservation: Challenges Beyond 2010. Science 329:1298-1303.

26. Tilman D, J. Fargione, B. Wolff, C. D“eAntonio, A. Dobson, R. Howarth, et al., (2001): Forecasting agriculturally driven global environmental change. Science 292:281-284.

27. Dereje Mosissa, Ashafi Mohammed (2019). The Effectiveness of Soil and Water Conservation asClimate Smart Agricultural Practice and Its Contribution to Smallholder Farmers' Livelihoods. The Case of Bambasi District Benishangul Gumuz Regional State, Northwest of Ethiopia. Journal of Biology, Agriculture and Healthcare. Vol.9, No.12.

28. NBSAP (2005). Ethiopian National Biodiversity Strategy and Action Plant 